Tjalling C. Koopmans Research Institute

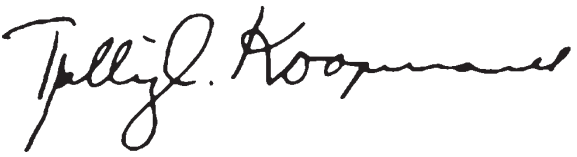

Discussion Paper Series nr: 14-08

\title{
Temporal and locational flexibility of work, working-time fit, and job satisfaction
}

Daniel Possenriede Janneke Plantenga 


\section{Tjalling C. Koopmans Research Institute Utrecht School of Economics \\ Utrecht University}

Kriekenpitplein 21-22

3584 EC Utrecht

The Netherlands

telephone $\quad+31302539800$

fax +31302537373

website www.koopmansinstitute.uu.nl

The Tjalling C. Koopmans Institute is the research institute and research school of Utrecht School of Economics.

It was founded in 2003, and named after Professor Tjalling C. Koopmans, Dutch-born Nobel Prize laureate in economics of 1975.

In the discussion papers series the Koopmans Institute publishes results of ongoing research for early dissemination of research results, and to enhance discussion with colleagues.

Please send any comments and suggestions on the Koopmans institute, or this series to L.M.vanDort@uu.nl

ontwerp voorblad: WR IK U trecht

\section{How to reach the authors}

Please direct all correspondence to the first author.

\section{Daniel Possenriede}

Janneke Plantenga

Utrecht University

Utrecht School of Economics

Kriekenpitplein 21-22

3584 TC Utrecht

The Netherlands.

E-mail: D.Possenriede@uu.nl

L.Plantenga@uu.nl

This paper can be downloaded at: http://

www.uu.nl/rebo/economie/discussionpapers 


\title{
Temporal and locational flexibility of work, working-time fit, and job satisfaction
}

\author{
Daniel Possenriedeab \\ Janneke Plantenga \\ ${ }^{\text {a Utrecht School of Economics }}$ \\ Utrecht University

\begin{abstract}
This study analyses the effects of arrangements that provide temporal and locational flexibility of work (TLF), namely flexi-time, telehomework, and part-time work, on employees' satisfaction with the fit between working time and private life and their overall job satisfaction. TLF arrangements provide employees with more control over their working life and therefore are likely to improve on the match between paid work and private life. Based on Dutch household panel data, the results show that TLF arrangements, flexi-time in particular, are generally associated with sizeable increases in satisfaction with working-time fit and overall job satisfaction. Somewhat surprisingly, the effects hardly differ between male and female employees and between employees with and without children. Temporal and locational flexibility apparently appeals not only to employees with family responsibilities but more general to all employees.
\end{abstract}

Keywords: flexi-time; job satisfaction; locational flexibility; part-time work; telehomework; temporal flexibility; working-time fit

JEL classification: J22; J 28; M52; M54

\section{Acknowledgements}

The authors thank Emre Akgündüz, Heejung Chung, Wolter Hassink, Thomas van Huizen, and Ferry Koster as well as participants of the Community, Work \& Family IV International Conference for helpful comments and suggestions. Data provision by Sociaal en Cultureel Planbureau and financial support by Instituut Gak are gratefully acknowledged. 


\section{Introduction}

In recent years there has been a shift in many industrialised countries from jobs with fixed schedules carried out on a full-time basis on the premisses of the employer towards more flexible forms of work organisation, where employees can choose and modify within certain boundaries - when, where, and how long they work. This trend towards temporal and locational flexibility of work (TLF) is the result of an individualizing work force, the need of employees to combine paid work with other (unpaid) activities and thus a growing demand for employee-centred working time arrangements. Employers on the other hand increasingly provide these arrangements to their employees not only to increase their own flexibility and competitiveness but also to attract and retain qualified personnel. This all happens against the backdrop of an ageing society, expectations of labour force shortages, and the proliferation of new information technology, which facilitates this increase in TLF (Plantenga, 2003).

If TLF arrangements indeed improve the fit between paid work and other activities, this should be reflected in employees' overall job satisfaction. This paper assesses whether this is the case by analysing the effects of TLF arrangements on self-reported satisfaction with working-time fit and overall job satisfaction of Dutch employees. We consider three TLF arrangements at the same time, i.e. flexibility in the work schedule (flexi-time), location (telehomework) and duration (part-time). These arrangements often come in bundles and can be substituted and combined (Chung, 2009). Since analysing these arrangements in isolation may lead to biased results, it is important to examine them jointly. In addition this combined approach facilitates the comparison of relative effects of the arrangements. The analysis is based on a large, longitudinal household dataset that makes it possible to study the relation between different TLF arrangements and satisfaction while controlling for various confounding factors.

Identifying job arrangements and characteristics that affect job satisfaction and working-time fit is relevant for various labour market domains. Job satisfaction has thus been on the agenda of economics and sociology since at least the 1970s (Hamermesh, 1977; Kalleberg, 1977; Freeman, 1978; Borjas, 1979). Despite its subjectivity it has increasingly been viewed as a comprehensive measure of employees' utility from the job (Clark, 1996; Clark and Oswald, 1996). Job satisfaction is a predictor for quits, lay-offs and job transitions (Freeman, 1978; Akerlof et al., 1988; Clark, 2001), as well as health and absenteeism (Faragher et al., 2005; Roelen et al., 2008; Fischer and Sousa-Poza, 2009). It is also positively associated with productivity (Argyle, 1989; Judge et al., 2001; Zelenski et al., 2008; Böckerman and Ilmakunnas, 2012) and organisational performance (Ostroff, 1992). Due to its reciprocal impact on overall well-being (Judge and Watanabe, 1993), job satisfaction is also increasingly perceived as an end in itself (Saltzstein et al., 2001).

The results show that TLF is generally associated with better working-time fit and higher job satisfaction scores, with access to flexi-time having the largest impact. Tele- 
homework does not significantly increase working-time fit, though. For part-time work we even find a negative association with overall job satisfaction, which is in line with theory but contrasts some previous empirical findings. Interestingly, there are no considerable gender differences in the effects of TLF in general and also no differences in the associations between flexibility, working-time fit, and job satisfaction between employees with and without family responsibilities. TLF apparently appeals not only to employees with family responsibilities but more generally to all employees.

\section{Theoretical framework}

In comparison to the 40 hour working week and 8 hour workdays that constitute the de-facto standard in most industrialized countries today (Bosch, 1999; Parent-Thirion et al., 2007), TLF arrangements make it possible to modify the schedule (e.g. flexi-time), location (telehomework), and duration (part-time) of work. These variations in the organizational aspects of paid work provide (time) autonomy and flexibility to workers and can improve the fit between paid work and other activities (Fagan, 2004; Hill et al., 2008). TLF arrangements are usually not available and used in isolation but in various combinations. They may complement and substitute each other and should therefore be examined jointly to prevent possible biases (Kalleberg et al., 2003; Chung, 2009).

Both the relationships between TLF and satisfaction with working-time fit and between TLF and overall job satisfaction are investigated. The impact of TLF on satisfaction with working-time fit indicates whether TLF arrangements are effective in reconciling work and private life and improving perceived work-life fit. The relation between TLF arrangements and overall job satisfaction shows whether these arrangements have a substantive influence among the whole bundle of factors affecting utility from work. In other words, does TLF play a significant role for overall job satisfaction?

In order to analyse the effect of TLF on an employee's utility from working, a simple bottom-up model (Diener, 1984) ${ }^{1}$ is used, which, if only implicitly, has been implemented before in many other economic studies on the determinants of job satisfaction (SousaPoza and Sousa-Poza, 2000b). The bottom-up approach used here basically assumes that individual job satisfaction is the net sum of work-role inputs (such as education, working time and effort) and work-role outputs (such as wages, fringe benefits, status, (favourable) working conditions and intrinsic aspects) (Hulin et al., 1985; Judge and Watanabe, 1993; Sousa-Poza and Sousa-Poza, 2000b). Each work-role input (output) is associated with a negative (positive) utility and depending on whether the resulting net

\footnotetext{
${ }^{1}$ The corresponding top-down theories assume that an individual's "global features of personality are thought to influence the way a person reacts to events" (Diener, 1984). According to this view "subjective domain satisfactions derive from, rather than cause, overall subjective well-being" (Diener, 1984). Since our aim is to analyze determinants of job satisfaction, a top-down approach is not applicable.
} 
sum is positive or negative, overall job satisfaction (or facets thereof) will be positive or negative. Formally, an individual's utility from work can then be written as:

$$
U_{w}=\sum\left(W_{\text {output }}-W_{\text {input }}\right)
$$

TLF is expected to have a positive impact on utility from work in general. TLF provides employees with more control and autonomy over their (working) life, and therefore improves on the match between paid work and private life (Hill et al., 2001, 2008). TLF also allows employees to work during times more suited to their personal needs and biological clock and may decrease the amount of work- and commuting-related stress experienced by the employees, thereby optimizing their efforts (Scandura and Lankau, 1997; Baltes et al., 1999). In addition, TLF may signal to employees that their employer cares about their well-being and their responsibilities outside work (Grover and Crooker, 1995; Casper and Harris, 2008). In summary, TLF is expected to provide positive utility from work and should therefore be considered a work-role output.

Previous empirical research on schedule flexibility and flexi-time in particular finds a positive association with job satisfaction and satisfaction with the work schedule (Baltes et al., 1999; Cotti et al., 2013) as well as organisational commitment and satisfaction with the employer (Grover and Crooker, 1995; Scandura and Lankau, 1997; Kelliher and Anderson, 2010). For location flexibility the evidence is more ambiguous. Whereas Bailey and Kurland (2002) find little evidence in their meta-analysis that telehomework increases job satisfaction, Gajendran and Harrison (2007) do find positive impacts on job satisfaction, mostly because it improves perceived autonomy. They argue that "telecommuting indirectly influences job satisfaction, [...] by raising perceptions of control over the location, timing, and means of completing one's work" (Gajendran and Harrison, 2007). These mixed findings hint at a complex, possibly hump-shaped relation between the extent of telehomework utilisation and job satisfaction (Golden and Veiga, 2005; Virick et al., 2010). Telehomework potentially leads to blurring boundaries between work and private life (Kossek et al., 2006), therefore exerting a negative effect on perceived fit between working time and private life and possibly job satisfaction in general (Saltzstein et al., 2001; Peters and van der Lippe, 2007; Peters et al., 2009). Telehomework also reduces direct interaction with colleagues and supervisors and may therefore lead to increased team conflict (Hinds and Bailey, 2003), as well as less organisational commitment and satisfaction with the employer (ten Brummelhuis et al., 2010). These drawbacks most likely increase with the extent of telehomework utilisation (Golden, 2006).

Duration flexibility is expected to have a positive impact on working-time fit, because employees can adjust the number of hours to their needs and more time is available for private activities. With respect to overall job satisfaction, part-time work is generally associated with low occupational status and lower hourly wages (Manning and Petron- 
golo, 2008), as well as fewer opportunities for training and career advancement (Sandor, 2011). Since it mainly occurs in marginalised and menial jobs, it further leads to occupational downgrading (Connolly and Gregory, 2008). Part-time work is therefore often considered to be intrinsically unsatisfying and should be associated with lower levels of job satisfaction (Booth and van Ours, 2008, 2009, 2013). These effects may be less relevant in the Netherlands than elsewhere, though, since the majority of part-time work is done voluntarily and has been promoted by public policy (Plantenga, 2002; Visser, 2002; Cousins and Tang, 2004; Portegijs and Keuzenkamp, 2008). ${ }^{2}$ Previous empirical results regarding the relation between part-time work and job satisfaction are also ambiguous. Booth and van Ours for example find positive effects for the UK (2008), no or slightly positive effects for Australia (2009) ${ }^{3}$, and negative effects for the Netherlands (2013). ${ }^{4}$

The impact of TLF on satisfaction with working-time fit is likely to be stronger than the impact on overall job satisfaction, since the latter is influenced by many more factors. ${ }^{5}$ The effects on overall job satisfaction may in fact be composite: On the one hand TLF may increase satisfaction with the job and the employer through increased autonomy, work-life balance and self-determination. On the other hand TLF may decrease satisfaction through negative effects on the career and a feeling of being a 'lonesome worker' (less team spirit, organisational commitment, etc.).

The considerations above translate into the following hypotheses:

Hypothesis 1a: TLF is positively associated with working-time fit and overall job satisfaction.

Hypothesis 1b: The size of the associations is strongest for schedule flexibility and weakest for duration flexibility, with location flexibility in between.

Hypothesis 1c: The associations are stronger for satisfaction with working-time fit than for overall job satisfaction.

\footnotetext{
${ }^{2}$ In the Netherlands, being the "only part-time economy in the world" (Freeman, 1998) part-time employment is not limited to marginal jobs, but rather a widespread feature of mainstream employment (Portegijs and Keuzenkamp, 2008). Part-time employment in the Netherlands nevertheless leads to foregone promotions and lower future wage growth, too (Román, 2006; Russo and Hassink, 2008).

${ }^{3}$ Booth and van Ours (2009) find no effects when using a simple part-time dummy $(<35 \mathrm{~h})$ and positive effects with more disaggregated hours categories.

${ }^{4}$ For their job satisfaction analysis, Booth and van Ours (2013) also use the Dutch Labour Supply Panel (see below), but with a different time frame (1992-2006) and (almost) no time-variant control variables. Note also that they restrict their samples to married or cohabiting employees in all three studies. Finally, while all results from the three studies are based on fixed-effects ordered logit specifications, they use an estimator based on the one developed by Ferrer-i-Carbonell and Frijters (2004), which has been shown to produce biased parameter estimates in Monte-Carlo simulations (Baetschmann et al., 2011; Dickerson et al., 2012; Riedl and Geishecker, 2012).

${ }^{5}$ Sloane and Williams (2000) for example find that the nature of work itself accounts for most of the overall job satisfaction.
} 
TLF is likely to affect working-time fit and overall job satisfaction differently for different groups. Previous research on job satisfaction for example found a gender gap, i.e. women report on average higher levels of job satisfaction than men (Dalton and Marcis, 1987; Clark, 1997; Sousa-Poza and Sousa-Poza, 2000a). Since females are on average worse-off in the labour market in terms of pay, career opportunities and working conditions, this gender gap seems quite paradoxical. Some authors therefore hypothesized that the gender gap in job satisfaction may be caused by self-selection of women into certain jobs (Bender et al., 2005; Asadullah and Fernández, 2008). In order to combine paid work with family responsibilities, women predominantly prefer jobs that offer TLF and other work-life balance (WLB) policies and therefore choose jobs that offer these. The existing empirical evidence is not fully conclusive though. While not explicitly addressing the gender gap, Scandura and Lankau (1997) observe that flexible work hours lead to higher job satisfaction and organizational commitment for female employees and for employees with family responsibilities. Bender et al. (2005) show that scheduling flexibility and the perception of not having to choose between job and family/personal life is valued more by female employees and eliminates the gender gap in job satisfaction. Asadullah and Fernández (2008) on the other hand do not find significant gender differences in the effect of WLB policies on job satisfaction in general. In any case, these previous findings should prompt us to examine the differences in the effects of TLF for employees with and without family responsibilities.

Hypothesis 2: TLF increases the probability of reporting higher levels of satisfaction with working-time fit and with overall job satisfaction more for employees with familyresponsibilities than for those without.

\section{Methodology}

\subsection{Data}

For the analysis the Dutch Labour Supply Panel (Arbeidsaanbodpanel, AAP), a biennial panel survey of a representative sample of Dutch households. ${ }^{6}$ The panel survey is conducted to study developments in labour market behaviour and working conditions in the Netherlands and covers a broad range of work- and life-course-related items. The target population consists of the Dutch labour force aged 16 to 66 years. The AAP has existed since 1985, but questions about (tele-)homework were first asked in 2002, so only the waves from 2002 onwards are suitable for an analysis of TLF. This means that we have five waves available for this analysis, for every other year since 2002 to the last

\footnotetext{
${ }^{6}$ The panel was formerly known as the OSA Labour Supply Panel is now conducted on behalf of the Social en Cultureel Planbureau. The data and its documentation are in Dutch and available via http://easy.dans.knaw.nl (urn:nbn:nl:ui:13-4js-j13).
} 
publicly available wave from 2010 . We restrict the sample to employees (i.e. we exclude self-employed, unemployed, full-time students, etc.), which results in an unbalanced panel of 17,136 observations from 7,771 individuals (gross sample). For further analysis we excluded those observations with missing values on any of the variables used in the analysis (net sample). Table 1 presents an overview and descriptive statistics of the variables used in the analysis.

Self-reported measures of job satisfaction are used as a proxy for the individual utility derived from working. These measures are widely used indicators of well-being and have been shown to be closely related to a range of other - potentially more objective - measures of happiness (Freeman, 1978; Frey and Stutzer, 2002; Kristensen and Westergaard-Nielsen, 2007). In the AAP, the job satisfaction variable is obtained from the following question and measured on a 4-point Likert-scale.

'How satisfied are you, everything included, with your job?'

The variable on working-time fit is measured on a 5-point Likert-scale and acquired from this question:

'To what extent do you agree with the following statements? [...]

"I can let my working hours fit in well with my home situation."'

The main independent variables and indicators for TLF are flexi-time, telehomework, and part-time work. Flexi-time and telehomework are coded as dummy variables. The flexi-time variable was obtained from the following survey question:

'Can you say whether each of the following characteristics does or does not apply to the work you do? [...] "Determine start- and end-time myself"'

The telehomework variable was obtained from the following question:

'Do you work at home every now and then in your current job?'

We only count those respondents as telehomeworkers who state that they work at home once a week on average. ${ }^{7}$ On average, $39 \%$ of the respondents in the sample can determine the start- and end-times of their work and $17 \%$ work at home at least once a week.

The part-time variable contains four categories (small, medium, large part-time and full-time) and was created on the basis of a question on contracted hours:

\footnotetext{
${ }^{7}$ Telehomeworkers were asked how often they were working at home on average. From 2004 onwards the answer categories were less than once per month, less than twice per month, once per week or twice or more often per week. We only count the latter two categories as telehomeworkers. In 2002 the answer categories were once per month, twice per month, three times per month, more than three times per month. We include only the latter as telehomeworkers.
} 
'How many hours do you work according to your contract? Overtime-hours should not be considered. ${ }^{8}$

A large set of control variables was used, which is outlined in table 1. The controls follow the social sciences literature on job satisfaction and measure observable personal and household as well as job and employer characteristics. Most control variables are measured as dummy or categorical variables.

\subsection{Statistical model}

The starting point of our analysis is the following model:

$$
Y_{i t}^{*}=\beta^{\prime} X_{i t}+\alpha_{i}+\varepsilon_{i t}
$$

where $Y_{i t}^{*}$ is a measure of working-time fit or job satisfaction, respectively, of individual $i$ at time $t, X_{i t}$ is a vector of observable characteristics, and $\beta$ is a vector of parameters to be estimated. ${ }^{9} \alpha_{i}$ is the time-invariant, individual-specific part of the unobservables, which may be correlated with $x_{i t}$, and $\varepsilon_{i t}$ is an idiosyncratic error term. Since unobservable personal and job-related traits are likely to be correlated with job satisfaction and working-time fit, we treat $\alpha_{i}$ as a fixed effect (Diener, 1984; Ferrer-i-Carbonell and Frijters, 2004).

Job satisfaction and working-time fit are measured as categorical variables, so the observed variable $Y_{i t}$ is related to the latent variable $Y_{i t}^{*}$ as follows:

$$
Y_{i t}=k \quad \text { if } \quad \tau_{i k}<Y_{i t}^{*} \leq \tau_{i k+1}, \quad k=1, \ldots, K,
$$

where individual-specific thresholds $\tau_{i}$ are increasing, i.e. $\left(\tau_{i k} \leq \tau_{i k+1} \forall k\right), \tau_{i 1}=-\infty$, and $\tau_{i K+1}=\infty$.

We estimate equation (1) with two different specifications. First we utilize a linear fixed-effects (linear FE) specification, which implies that $Y_{i t}=Y_{i t}^{*}$. This essentially imposes a cardinal interpretation of the dependent variables. While this may be somewhat worrisome for economists, Ferrer-i-Carbonell and Frijters (2004) find that 'assuming ordinality or cardinality of happiness scores makes little difference', whereas 'allowing for fixed-effects does change results substantially'. Whether cardinality may be rightfully assumed probably depends on the aggregation level, i.e. the number of categories, of the outcome variable (Riedl and Geishecker, 2012). Our outcome variables only have 4 or 5 categories, respectively, whereas it had 11 categories in Ferrer-i-Carbonell and Frijters' (2004) article, so cardinality may still be a strong assumption in our case. The advantage

\footnotetext{
${ }^{8}$ The literal translation of the survey question is 'what is the size of your appointment?' We use a categorical instead of a continuous variable in order to account for potential non-linearities in the effects.

${ }^{9}$ We omit an index to denote the two different outcome variables and the independent variables and parameters associated with it for simplicity.
} 
Table 1: Descriptive statistics

\begin{tabular}{|c|c|c|c|c|c|c|}
\hline \multirow[b]{2}{*}{ Variables } & \multicolumn{2}{|c|}{ Gross sample } & \multicolumn{2}{|c|}{ Net sample } & \multirow[b]{2}{*}{ Min } & \multirow[b]{2}{*}{ Max } \\
\hline & Mean & S.E. & Mean & S.E. & & \\
\hline Job satisfaction & 3.24 & $(0.005)$ & 3.24 & $(0.006)$ & 1 & 4 \\
\hline Work hours fit & 3.94 & $(0.008)$ & 3.93 & $(0.009)$ & 1 & 5 \\
\hline Flexi-time & 0.37 & $(0.004)$ & 0.39 & $(0.004)$ & 0 & 1 \\
\hline Telehomework & 0.17 & $(0.003)$ & 0.17 & $(0.003)$ & 0 & 1 \\
\hline \multicolumn{7}{|l|}{ Contracted hours } \\
\hline Small part-time $(1-11 \mathrm{~h})$ & 0.07 & $(0.002)$ & 0.04 & $(0.002)$ & 0 & 1 \\
\hline Medium part-time (12 - 19h) & 0.11 & $(0.002)$ & 0.10 & $(0.003)$ & 0 & 1 \\
\hline Large part-time $(20-35 \mathrm{~h})$ & 0.31 & $(0.004)$ & 0.32 & $(0.004)$ & 0 & 1 \\
\hline Full-time $(36+\mathrm{h})$ & 0.52 & $(0.004)$ & 0.53 & $(0.005)$ & 0 & 1 \\
\hline \multicolumn{7}{|l|}{ Marital status } \\
\hline Married & 0.64 & $(0.004)$ & 0.68 & $(0.004)$ & 0 & 1 \\
\hline Cohabiting & 0.11 & $(0.002)$ & 0.11 & $(0.003)$ & 0 & 1 \\
\hline Single & 0.24 & $(0.003)$ & 0.20 & $(0.004)$ & 0 & 1 \\
\hline Child(ren) & 0.53 & $(0.004)$ & 0.56 & $(0.004)$ & 0 & 1 \\
\hline \multicolumn{7}{|l|}{ Education } \\
\hline Primary school & 0.03 & $(0.001)$ & 0.02 & $(0.001)$ & 0 & 1 \\
\hline Lower secondary & 0.23 & $(0.003)$ & 0.22 & $(0.004)$ & 0 & 1 \\
\hline Higher secondary & 0.39 & $(0.004)$ & 0.38 & $(0.004)$ & 0 & 1 \\
\hline Vocational college & 0.25 & $(0.003)$ & 0.27 & $(0.004)$ & 0 & 1 \\
\hline Academic & 0.10 & $(0.002)$ & 0.11 & $(0.003)$ & 0 & 1 \\
\hline Work experience & 20.40 & $(0.087)$ & 20.97 & (0.099) & 0 & 52 \\
\hline Wage per hour & 11.85 & $(0.041)$ & 11.94 & $(0.043)$ & 1 & 100 \\
\hline Permanent contract & 0.83 & $(0.003)$ & 0.88 & $(0.003)$ & 0 & 1 \\
\hline Supervisor & 0.30 & $(0.003)$ & 0.32 & $(0.004)$ & 0 & 1 \\
\hline 2nd job & 0.07 & $(0.002)$ & 0.07 & $(0.002)$ & 0 & 1 \\
\hline \multicolumn{7}{|l|}{ Occupational level } \\
\hline Elementary & 0.06 & $(0.002)$ & 0.04 & $(0.002)$ & 0 & 1 \\
\hline Lower & 0.25 & $(0.003)$ & 0.22 & $(0.004)$ & 0 & 1 \\
\hline Medium & 0.35 & $(0.004)$ & 0.37 & $(0.004)$ & 0 & 1 \\
\hline Higher & 0.26 & $(0.003)$ & 0.28 & $(0.004)$ & 0 & 1 \\
\hline Scientific & 0.07 & $(0.002)$ & 0.08 & $(0.002)$ & 0 & 1 \\
\hline Empl. status change & 0.35 & $(0.004)$ & 0.33 & $(0.004)$ & 0 & 1 \\
\hline No. of employees $(/ 1000)$ & 0.50 & $(0.017)$ & 0.53 & $(0.019)$ & 0 & 70 \\
\hline \multicolumn{7}{|l|}{ Sector } \\
\hline Agriculture & 0.01 & $(0.001)$ & 0.01 & $(0.001)$ & 0 & 1 \\
\hline Industry & 0.11 & $(0.002)$ & 0.12 & $(0.003)$ & 0 & 1 \\
\hline Construction & 0.04 & $(0.001)$ & 0.04 & $(0.002)$ & 0 & 1 \\
\hline Trade, gastronomy, repair & 0.16 & $(0.003)$ & 0.14 & $(0.003)$ & 0 & 1 \\
\hline Transport & 0.06 & $(0.002)$ & 0.06 & $(0.002)$ & 0 & 1 \\
\hline Business services & 0.16 & $(0.003)$ & 0.17 & $(0.003)$ & 0 & 1 \\
\hline Care, Welfare & 0.21 & $(0.003)$ & 0.20 & $(0.004)$ & 0 & 1 \\
\hline Other services & 0.05 & $(0.002)$ & 0.05 & $(0.002)$ & 0 & 1 \\
\hline Government & 0.09 & $(0.002)$ & 0.10 & $(0.003)$ & 0 & 1 \\
\hline
\end{tabular}


Table 1: Descriptive statistics (cont.)

\begin{tabular}{lcccccccc}
\hline \multirow{2}{*}{ Variables } & \multicolumn{2}{c}{ Gross sample } & & \multicolumn{2}{c}{ Net sample } & & \\
\cline { 2 - 3 } & Mean & S.E. & & Mean & S.E. & Min & Max \\
\hline Education & 0.11 & $(0.002)$ & & 0.11 & $(0.003)$ & 0 & 1 \\
2002 & 0.18 & $(0.003)$ & & 0.14 & $(0.003)$ & 0 & 1 \\
2004 & 0.19 & $(0.003)$ & & 0.21 & $(0.004)$ & 0 & 1 \\
2006 & 0.22 & $(0.003)$ & & 0.22 & $(0.004)$ & 0 & 1 \\
2008 & 0.21 & $(0.003)$ & & 0.24 & $(0.004)$ & 0 & 1 \\
2010 & 0.20 & $(0.003)$ & & 0.19 & $(0.004)$ & 0 & 1 \\
\hline Observations & 17136 & & 12292 \\
\hline
\end{tabular}

Note: The gross sample comprises the observations of all employees in the sample, the net sample the observations used for estimation after list-wise deletion due to missing values. S.E. is the standard error of the mean.

of such as simple specification, however, is that the parameters can be easily interpreted as marginal effects.

In order to relax the cardinality assumption we also estimate a fixed-effects ordered logit model. In particular we apply the blow-up and cluster (BUC) estimator developed by Baetschmann et al. (2011). ${ }^{10}$ The authors provide a comprehensive review of different fixed-effect ordered logit estimators and their Monte-Carlo simulations show that the BUC estimator has the advantage of being consistent, robust in finite samples, and easily implemented. Dickerson et al. (2012) and Riedl and Geishecker (2012) provide further assessments of these estimators and draw similar conclusions. ${ }^{11}$

\section{Results}

Simple cross-tabulations of working-time fit and job satisfaction on the one hand and the three TLF arrangements under consideration on the other already show large differentials in the association of the different types of TLF with working-time fit and job satisfaction. Employees with flexi-time agree considerably more often with the statement that they can fit their working times well with their home-situation (see table 2). In the 'strongly agree' category there is an almost 12 percentage points difference between these two groups of employees. Part-time work is also associated with an increase in working-time fit according to these descriptives. The percentages of employees who state that they 'strongly disagree', 'disagree', or that they are 'neutral' with the statement increase with working time. The percentages of employees that 'strongly agree' with the statement sharply declines across the working time categories; the difference in

\footnotetext{
${ }^{10}$ An equivalent estimator was introduced in the biostatistics literature by Mukherjee et al. (2008).

${ }^{11}$ See Frijters and Beatton (2012) and Geishecker et al. (2012) for other applied work using the BUC estimator.
} 
Table 2: Working time fit by TLF arrangements

\begin{tabular}{lccccc}
\hline & \multicolumn{5}{c}{ Working times fit well with 'home-situation' } \\
\cline { 2 - 6 } & Strongly disagree & Disagree & Neutral & Agree & Strongly agree \\
\hline Flexi-time & & & & \\
\hline No & 4.24 & 8.31 & 19.05 & 41.61 & 26.80 \\
& $(0.27)$ & $(0.35)$ & $(0.51)$ & $(0.65)$ & $(0.63)$ \\
Yes & 1.02 & 3.65 & 12.54 & 44.69 & 38.09 \\
& $(0.15)$ & $(0.28)$ & $(0.52)$ & $(0.80)$ & $(0.84)$ \\
\hline Telehomework & & & & & \\
\hline No & 3.05 & 6.54 & 16.48 & 42.64 & 31.29 \\
& $(0.19)$ & $(0.27)$ & $(0.42)$ & $(0.56)$ & $(0.58)$ \\
Yes & 2.67 & 6.25 & 16.69 & 43.63 & 30.76 \\
& $(0.39)$ & $(0.56)$ & $(0.88)$ & $(1.17)$ & $(1.15)$ \\
\hline Contracted hours & \multicolumn{5}{c}{} \\
\hline Small part-time (1-11h) & 1.66 & 4.24 & 9.23 & 39.67 & 45.20 \\
Medium part-time (12-19h) & $(0.55)$ & $(0.86)$ & $(1.24)$ & $(2.33)$ & $(2.42)$ \\
& 2.08 & 4.07 & 13.10 & 40.02 & 40.73 \\
Large part-time (20-35h) & $(0.42)$ & $(0.60)$ & $(1.07)$ & $(1.52)$ & $(1.65)$ \\
& 2.81 & 5.36 & 14.72 & 42.89 & 34.22 \\
Full-time (36+h) & $(0.29)$ & $(0.39)$ & $(0.65)$ & $(0.91)$ & $(0.94)$ \\
& 3.38 & 7.82 & 18.86 & 43.55 & 26.39 \\
& $(0.25)$ & $(0.37)$ & $(0.53)$ & $(0.68)$ & $(0.66)$ \\
\hline Total & 2.99 & 6.49 & 16.51 & 42.81 & 31.20 \\
& $(0.18)$ & $(0.25)$ & $(0.38)$ & $(0.51)$ & $(0.53)$ \\
\hline
\end{tabular}

Note: Percentage of employees reporting how working times fit with 'home-situation' by TLF arrangements. Linearized standard errors of percentages in parentheses.

percentages between small-part time employees and full-time employees in this category is 19 percentage points. Telehomework on the other hand does not seem to make a difference with respect to working-time fit, since satisfaction with working-time fit is virtually the same whether employees occasionally work at home or not.

Both flexi-time and telehomework are positively associated with overall job satisfaction (table 3). The share of respondents who state that they are very satisfied with their job is almost seven percentage points higher when they can determine the start- and end-times of their work themselves than when they cannot. The same goes for employees who work at home at least once a week. Telehomework does not seem to make a marked difference at the lower end of the job satisfaction distribution, though, whereas fewer employees with flexi-time seem to be (very) dissatisfied with their job than those without. There are no clear differences in overall job satisfaction with respect to part-time work.

These cross-tabs do not account for any confounding factors like individual and job 
Table 3: Job satisfaction by TLF arrangements

\begin{tabular}{lcccc}
\hline & Very dissatisfied & Dissatisfied & Satisfied & Very satisfied \\
\hline Flexi-time & & & & \\
\hline No & 1.40 & 8.57 & 58.29 & 31.74 \\
& $(0.15)$ & $(0.37)$ & $(0.68)$ & $(0.67)$ \\
Yes & 0.90 & 6.91 & 53.56 & 38.63 \\
& $(0.14)$ & $(0.41)$ & $(0.86)$ & $(0.87)$ \\
\hline Telehomework & & & & \\
\hline No & 1.25 & 8.14 & 57.41 & 33.20 \\
& $(0.12)$ & $(0.31)$ & $(0.59)$ & $(0.59)$ \\
Yes & 1.00 & 6.87 & 51.74 & 40.39 \\
& $(0.23)$ & $(0.62)$ & $(1.27)$ & $(1.29)$ \\
\hline Contracted hours & & & \\
\hline Small part-time (1-11h) & 1.29 & 8.86 & 59.41 & 30.44 \\
\multirow{2}{*}{ Medium part-time (12-19h) } & $0.55)$ & $(1.29)$ & $(2.35)$ & $(2.26)$ \\
& 0.96 & 7.91 & 58.15 & 32.99 \\
Large part-time (20-35h) & $(0.28)$ & $(0.86)$ & $(1.62)$ & $(1.61)$ \\
& 1.62 & 7.59 & 54.20 & 36.60 \\
Full-time (36+h) & $(0.22)$ & $(0.45)$ & $(0.95)$ & $(0.97)$ \\
& 0.99 & 8.05 & 57.23 & 33.73 \\
& $(0.13)$ & $(0.39)$ & $(0.73)$ & $(0.73)$ \\
\hline Total & 1.20 & 7.92 & 56.44 & 34.43 \\
& $(0.11)$ & $(0.28)$ & $(0.56)$ & $(0.56)$ \\
\hline
\end{tabular}

Note: Percentage of employees reporting their job satisfaction by TLF arrangements. Linearized standard errors of percentages in parentheses.

characteristics. We therefore turn to the parameter estimates now. Specifications were estimated for male and female employees jointly and separately. The specification on the total sample is based on the assumption that male and female employees evaluate job characteristics similarly. This assumption may be too strong, however, since earlier studies have shown that men and women often value job and workplace characteristics differently (Sloane and Williams, 2000; Bender et al., 2005). By estimating separate regressions this restriction is relaxed, allowing for different utility functions for males and females regarding their job characteristics.

Table 4 shows the linear FE and BUC estimates of TLF arrangements on working-time fit. Similar to the cross-tabulations, flexi-time is positively associated with working-time fit, i.e. being able to determine the start- and end-times of work increases the probability of being satisfied with one's working time. The coefficients on telehomework are not significantly different from zero at conventional levels of significance, suggesting that working from home at least once a week does not improve working-time fit. This is con- 
sistent with the simple cross-tabulations as well. Part-time work is positively associated with working-time fit, small- and medium-sized part-time jobs with up to $20 \mathrm{~h}$ per week in particular. Here the coefficients are comparable in size with those on flexi-time. ${ }^{12}$ Large part-time jobs also increase working-time fit compared to full-time jobs for the total sample, but to a smaller degree than jobs with less than $20 \mathrm{~h}$ per week.

Next, table 5 presents the parameter estimates of TLF arrangements on overall job satisfaction. Flexi-time again is positively and strongly significantly associated with job satisfaction. The coefficients of the linear FE specifications are about half the size of those on working-time fit and those of the BUC estimator are still a bit smaller. This suggests a smaller impact of flexi-time on job satisfaction than on working-time fit, which, as mentioned above, is expected. For the total sample the telehomework coefficient is positive and significant at the $5 \%$ level. It is not statistically significant for the female sample. Finally, part-time work seems to be negatively associated with overall job satisfaction for female employees. The statistical significance is low for the BUC estimator, however. For male employees the part-time coefficients are not significantly different from zero at conventional levels.

In order to test whether there are gender differences in the effects of TLF on workingtime fit and job satisfaction, the separate regression models that were estimated with the BUC estimator for male and female employees are combined into one model by seemingly unrelated estimation (Weesie, 1999; StataCorp, 2013). ${ }^{13}$ Wald tests for differences in the coefficients are performed then. According to these tests, the null hypothesis of equal coefficients on TLF arrangements is not rejected with respect to working-time fit nor job satisfaction at conventional levels of statistical significance. This implies that there are no gender differences in the association between TLF arrangements and working-time fit or job satisfaction.

For schedule flexibility hypotheses $1 \mathrm{a}$ to $1 \mathrm{c}$ are therefore not rejected by our data. Flexi-time is positively associated with working-time fit and job satisfaction and the associations are stronger than those of telehomework and stronger or equal to those of part-time work with the two outcome variables. The association of flexi-time with working time fit is also stronger than the one with job satisfaction. For location flexibility, the hypotheses are rejected with respect to working time fit by our data, because we do not find any significant results for telehomework here. Since we 'control' for flexi-time in the regressions, we assume that this variable picks up the schedule flexibility component that may be inherent in telehomework in most jobs. That is, employees may often be able to determine their working time when working from home. Telehomework is positively associated with overall job satisfaction, however, but the the association is weaker than

\footnotetext{
${ }^{12}$ The flexi-time coefficients are smaller but these differences are not statistically significant.

${ }^{13}$ Seemingly unrelated estimation combines the parameter estimates and associated variance-covariance matrices of two or more regression models, thereby making it possible to test cross-model hypotheses.
} 
Table 4: TLF arrangements on working-time fit

\begin{tabular}{|c|c|c|c|c|c|c|}
\hline \multirow[b]{2}{*}{ Variables } & \multicolumn{2}{|c|}{ Total } & \multicolumn{2}{|c|}{ Male } & \multicolumn{2}{|c|}{ Female } \\
\hline & Linear FE & BUC (OR) & Linear FE & BUC (OR) & Linear FE & BUC (OR) \\
\hline Flexi-time & $\begin{array}{l}0.205^{* * *} \\
(0.031)\end{array}$ & $\begin{array}{l}1.798^{* * *} \\
(0.160)\end{array}$ & $\begin{array}{l}0.185^{* * *} \\
(0.044)\end{array}$ & $\begin{array}{l}1.639 * * * \\
(0.193)\end{array}$ & $\begin{array}{l}0.224^{* * *} \\
(0.045)\end{array}$ & $\begin{array}{l}1.973^{* * *} \\
(0.273)\end{array}$ \\
\hline Telehomework & $\begin{array}{l}-0.028 \\
(0.036)\end{array}$ & $\begin{array}{c}0.911 \\
(0.092)\end{array}$ & $\begin{array}{l}-0.043 \\
(0.049)\end{array}$ & $\begin{array}{c}0.890 \\
(0.121)\end{array}$ & $\begin{array}{l}-0.005 \\
(0.054)\end{array}$ & $\begin{array}{c}0.936 \\
(0.142)\end{array}$ \\
\hline $\begin{array}{l}\text { Part-time work } \\
\text { Ref: Full-time }(36+h)\end{array}$ & & & & & & \\
\hline Small part-time $(1-11 \mathrm{~h})$ & $\begin{array}{l}0.308^{* * *} \\
(0.114)\end{array}$ & $\begin{array}{l}2.275^{* * *} \\
(0.712)\end{array}$ & $\begin{array}{c}0.206 \\
(0.324)\end{array}$ & $\begin{array}{c}1.586 \\
(1.241)\end{array}$ & $\begin{array}{l}0.295^{* *} \\
(0.131)\end{array}$ & $\begin{array}{l}2.358^{* *} \\
(0.874)\end{array}$ \\
\hline Medium part-time $(12-19 \mathrm{~h})$ & $\begin{array}{l}0.283^{* * *} \\
(0.082)\end{array}$ & $\begin{array}{l}1.973^{* * *} \\
(0.401)\end{array}$ & $\begin{array}{l}0.578^{* *} \\
(0.254)\end{array}$ & $\begin{array}{l}3.278^{* *} \\
(1.729)\end{array}$ & $\begin{array}{l}0.268^{* * *} \\
(0.100)\end{array}$ & $\begin{array}{l}1.899 * * \\
(0.480)\end{array}$ \\
\hline Large part-time $(20-35 \mathrm{~h})$ & $\begin{array}{l}0.116^{* *} \\
(0.052)\end{array}$ & $\begin{array}{l}1.326^{* *} \\
(0.184)\end{array}$ & $\begin{array}{c}0.044 \\
(0.071)\end{array}$ & $\begin{array}{c}1.086 \\
(0.225)\end{array}$ & $\begin{array}{l}0.158^{* *} \\
(0.075)\end{array}$ & $\begin{array}{l}1.511^{* *} \\
(0.296)\end{array}$ \\
\hline Observ & 12292 & 10614 & 6369 & 5739 & 5923 & 4875 \\
\hline Individuals & 6032 & 2295 & 3105 & 1217 & 2927 & 1078 \\
\hline
\end{tabular}

$* p<0.10, * * p<0.05, * * * p<0.01$

Note: Parameter estimates of TLF arrangements on working-time fit. BUC coefficients are odds-ratios; the reference point is therefore one. Clustered standard errors in parentheses. See table 8 for the full specification.

Table 5: TLF arrangements on job satisfaction

\begin{tabular}{|c|c|c|c|c|c|c|}
\hline \multirow[b]{2}{*}{ Variables } & \multicolumn{2}{|c|}{ Total } & \multicolumn{2}{|c|}{ Male } & \multicolumn{2}{|c|}{ Female } \\
\hline & Linear FE & BUC (OR) & Linear FE & $\mathrm{BUC}(\mathrm{OR})$ & Linear FE & $\mathrm{BUC}(\mathrm{OR})$ \\
\hline \multirow[t]{2}{*}{ Flexi-time } & $0.087^{* * *}$ & $1.505^{* * *}$ & $0.084^{* * *}$ & $1.528^{* * *}$ & $0.095^{* * *}$ & $1.581^{* * *}$ \\
\hline & $(0.023)$ & $(0.148)$ & $(0.030)$ & $(0.204)$ & $(0.035)$ & $(0.233)$ \\
\hline \multirow[t]{2}{*}{ Telehomework } & $0.061^{* *}$ & $1.326^{* *}$ & $0.082^{* *}$ & $1.469^{* *}$ & 0.043 & 1.172 \\
\hline & $(0.025)$ & $(0.153)$ & $(0.035)$ & $(0.245)$ & $(0.035)$ & $(0.188)$ \\
\hline \multicolumn{7}{|l|}{ Part-time work } \\
\hline \multicolumn{7}{|l|}{ Ref: Full-time $(36+h)$} \\
\hline \multirow[t]{2}{*}{ Small part-time $(1-11 \mathrm{~h})$} & $-0.168^{* *}$ & 0.586 & -0.149 & 0.581 & $-0.200^{* *}$ & 0.504 \\
\hline & $(0.084)$ & $(0.222)$ & $(0.234)$ & $(0.706)$ & $(0.096)$ & $(0.210)$ \\
\hline \multirow[t]{2}{*}{ Medium part-time $(12-19 \mathrm{~h})$} & $-0.132^{* *}$ & $0.642^{*}$ & 0.054 & 1.458 & $-0.194^{* * *}$ & $0.499 * *$ \\
\hline & $(0.057)$ & $(0.147)$ & $(0.162)$ & $(0.990)$ & $(0.072)$ & $(0.142)$ \\
\hline \multirow[t]{2}{*}{ Large part-time (20-35h) } & $-0.072^{* *}$ & $0.779 *$ & -0.045 & 0.842 & $-0.117^{* *}$ & $0.682^{*}$ \\
\hline & $(0.036)$ & $(0.118)$ & $(0.049)$ & $(0.205)$ & $(0.054)$ & $(0.142)$ \\
\hline Observations & 12292 & 6184 & 6369 & 3174 & 5923 & 3010 \\
\hline Individuals & 6032 & 1732 & 3105 & 881 & 2927 & 851 \\
\hline
\end{tabular}

${ }^{*} p<0.10,{ }^{* *} p<0.05,{ }^{* * *} p<0.01$

Note: Parameter estimates of TLF arrangements on job satisfaction. BUC coefficients are odds-ratios; the reference point is therefore one. Clustered standard errors in parentheses. See table 9 for the full specification. 
that between flexi-time and job satisfaction. Hypotheses $1 \mathrm{a}$ and $1 \mathrm{~b}$ are therefore not rejected for location flexibility with respect to job satisfaction. Duration flexibility is positively associated with working-time fit, in about the same order as flexi-time for work durations of up to 20 hours per week. With respect to overall job satisfaction, the hypotheses are rejected, however, since part-time work seems to have a negative effect here for female employees and no effect for male employees. Hypotheses 1a and 1c are therefore not rejected with respect to work duration. Finally, our results are qualitatively the same for both the linear FE and BUC estimators. Assuming cardinality or ordinality with respect to working-time fit and overall job satisfaction therefore does not seem to make much of a difference in this case.

In order to test hypothesis 2 , namely that TLF has a higher impact with respect to working-time fit and job satisfaction for employees with family responsibilities than for those without, we also estimated both specifications for employees with and without children (see tables 6 and 7). Once more, the BUC estimator results were combined by seemingly unrelated estimation and again the null hypothesis of equal coefficients is not rejected. The associations between TLF and working-time fit or job satisfaction do not appear to depend on family responsibilities, like having children at home. This result is further supported by the absence of significant gender differences as mentioned above. Hypothesis 2 is therefore rejected by our data.

A few limitations of this analysis need to be mentioned. Even though we control for many individual and job-related characteristics, including fixed effects, the estimates do not allow for a true causal interpretation, since we cannot control for unobserved time-varying factors. A common shock may potentially affect the availability and use of TLF arrangements and job satisfaction at the same time for example. Reverse causality may also potentially bias our estimates (i.e. more satisfied employees can make more use of TLF arrangements), even though previous research has not found this to be a considerable issue (Jonge et al., 2001). A drawback of our data is that we do not measure true location and duration flexibility, i.e. whether employees are able to actively influence and change the work location and duration, but rather the actual use of telehomework and part-time arrangements. ${ }^{14}$ Telehomework or part-time work may for example be (partly) determined by the employer, so our data measures the revealed outcome of a bargaining process between employer and employee rather than an employee's actual choice set. From this perspective, our estimates should be interpreted as a lower bound to the true estimates.

\footnotetext{
${ }^{14}$ For schedule flexibility we measure whether employees can determine their start- and end-times, i.e. whether employees can make choices in their schedule.
} 
Table 6: TLF arrangements on working-time fit by children at home

\begin{tabular}{|c|c|c|c|c|}
\hline & \multicolumn{2}{|c|}{ No children } & \multicolumn{2}{|c|}{ Child(ren) at home } \\
\hline & Linear FE & BUC (OR) & Linear FE & $\mathrm{BUC}(\mathrm{OR})$ \\
\hline Flexi-time & $\begin{array}{l}0.136^{* *} \\
(0.056)\end{array}$ & $\begin{array}{l}1.441^{* *} \\
(0.223)\end{array}$ & $\begin{array}{l}0.202^{* * *} \\
(0.040)\end{array}$ & $\begin{array}{l}1.790^{* * *} \\
(0.207)\end{array}$ \\
\hline Telehomework & $\begin{array}{l}-0.094 \\
(0.064)\end{array}$ & $\begin{array}{r}0.730^{*} \\
(0.139)\end{array}$ & $\begin{array}{c}0.002 \\
(0.047)\end{array}$ & $\begin{array}{c}0.990 \\
(0.128)\end{array}$ \\
\hline $\begin{array}{l}\text { Part-time work } \\
\text { Ref: Full-time }(36+h)\end{array}$ & & & & \\
\hline Small part-time $(1-11 \mathrm{~h})$ & $\begin{array}{l}0.528^{* * *} \\
(0.185)\end{array}$ & $\begin{array}{l}3.534^{* *} \\
(1.738)\end{array}$ & $\begin{array}{c}0.226 \\
(0.149)\end{array}$ & $\begin{array}{c}1.865 \\
(0.841)\end{array}$ \\
\hline Medium part-time (12-19h) & $\begin{array}{c}0.305 \\
(0.187)\end{array}$ & $\begin{array}{l}2.110^{* *} \\
(0.793)\end{array}$ & $\begin{array}{l}0.291^{* * *} \\
(0.106)\end{array}$ & $\begin{array}{l}2.121^{* * *} \\
(0.603)\end{array}$ \\
\hline Large part-time (20-35h) & $\begin{array}{c}0.103 \\
(0.075)\end{array}$ & $\begin{array}{c}1.281 \\
(0.255)\end{array}$ & $\begin{array}{r}0.134^{*} \\
(0.079)\end{array}$ & $\begin{array}{c}1.418 \\
(0.320)\end{array}$ \\
\hline Observations & 5402 & 3608 & 6890 & 6076 \\
\hline Individuals & 3239 & 898 & 3279 & 1279 \\
\hline
\end{tabular}

${ }^{*} p<0.10,{ }^{* *} p<0.05,{ }^{* * *} p<0.01$

Note: Parameter estimates of TLF arrangements on working-time fit. BUC coefficients are odds-ratios; the reference point is therefore one. Clustered standard errors in parentheses. See table 10 for the full specification.

Table 7: TLF arrangements on job satisfaction by children at home

\begin{tabular}{|c|c|c|c|c|}
\hline & \multicolumn{2}{|c|}{ No children } & \multicolumn{2}{|c|}{ Child(ren) at home } \\
\hline & Linear FE & BUC (OR) & Linear FE & $\mathrm{BUC}(\mathrm{OR})$ \\
\hline \multirow[t]{2}{*}{ Flexi-time } & $0.066^{*}$ & $1.379 *$ & $0.078^{* * *}$ & $1.452^{* * *}$ \\
\hline & $(0.038)$ & $(0.229)$ & $(0.030)$ & $(0.186)$ \\
\hline \multirow[t]{2}{*}{ Telehomework } & 0.030 & 1.139 & $0.069^{* *}$ & $1.380^{* *}$ \\
\hline & $(0.042)$ & $(0.234)$ & $(0.034)$ & $(0.215)$ \\
\hline \multicolumn{5}{|l|}{ Part-time work } \\
\hline \multicolumn{5}{|l|}{ Ref: Full-time $(36+h)$} \\
\hline \multirow[t]{2}{*}{ Small part-time $(1-11 \mathrm{~h})$} & -0.145 & 0.671 & $-0.187^{*}$ & 0.473 \\
\hline & $(0.142)$ & $(0.415)$ & $(0.112)$ & $(0.238)$ \\
\hline \multirow[t]{2}{*}{ Medium part-time (12-19h) } & -0.148 & 0.636 & -0.117 & 0.620 \\
\hline & $(0.092)$ & $(0.239)$ & $(0.085)$ & $(0.210)$ \\
\hline \multirow[t]{2}{*}{ Large part-time (20-35h) } & $-0.114^{* *}$ & $0.678^{*}$ & -0.054 & 0.777 \\
\hline & $(0.054)$ & $(0.150)$ & $(0.059)$ & $(0.199)$ \\
\hline Observations & 5402 & 2110 & 6890 & 3549 \\
\hline Individuals & 3239 & 672 & 3279 & 973 \\
\hline
\end{tabular}

${ }^{*} p<0.10,{ }^{* *} p<0.05,{ }^{* * *} p<0.01$

Note: Parameter estimates of TLF arrangements on job satisfaction. BUC coefficients are odds-ratios; the reference point is therefore one. Clustered standard errors in parentheses. See table 11 for the full specification. 


\section{Conclusion}

Temporal and locational flexibility of work is an important element in current policy debates about working conditions and the combination of work and private life (see e.g. CEA, 2010; Sociaal-Economische Raad, 2011; BMFSFJ, 2012). Flexibility is not only viewed as a means to improve the competitiveness of enterprises, but can also provide employees with a greater scope to reconcile their professional, private, and family lives. Furthermore TLF is expected to increase female labour participation and reduce shortages of qualified personnel in the future.

This paper analyses whether TLF arrangements, namely flexi-time, telehomework, and part-time work, improve the fit between working time and private life and increase employee's overall job satisfaction. The main premise is that TLF provides employees with more control over their working life, leads to a better match between paid work and other activities, decreases the amount of stress experienced by employees and signals to employees that their employer cares about their well-being and their responsibilities outside work. A simple bottom-up model is used under the assumption that utility from work is the sum of work-role inputs and outputs. The items that are employed to measure utility from work are self-reported working-time fit and overall job satisfaction.

The main results of this analysis are the following: Schedule flexibility in the form of flexible, self-determined start- and end-times of work is positively associated with both working-time fit and job satisfaction. Telehomework or location flexibility is also related to higher job satisfaction, although to a smaller extent than flexi-time. It does not seem to affect working-time fit in a significant way, however. Part-time work, i.e. schedule flexibility, finally increases working-time fit much in the same way as flexi-time. Our estimates show no significant association with overall job satisfaction for male employees, however, and sometimes even negative ones for female employees. Apart from that we hardly find any gender differences in the effects of TLF on working-time fit and job satisfaction. TLF also does not seem to be particularly more relevant for employees with family responsibilities, a group of workers who presumably struggle more with the combination of work and private life than other groups of workers. The associations of TLF with working-time fit and job satisfaction for this group are in any case quite similar to those for employees without children at home.

The conclusions that can be drawn from this analysis is that schedule flexibility may be a superior alternative to duration flexibility with respect to the combination of work and private life. It is similarly associated with good working-time fit, seems to have a positive effect on job satisfaction and does not appear to be the career liability that part-time work often is. Location flexibility does not seem to support the combination of work and private life in a significant way - at least not with respect to working-time fit. It presumably improves workers' autonomy, though, and thus increases job satisfaction. Since previous research has shown that higher job satisfaction translates into fewer 
job quits, a lower rate of absenteeism and increased general well-being, this would be beneficial to both employers and employees. The result that part-time work is negatively associated with job satisfaction for females is remarkable, because even though it is in line with what theory would predict considering the occupational drawbacks of part-time work (Connolly and Gregory, 2008; Manning, 2003), it contrasts some of the previous empirical results on the supposedly contented part-time worker (Booth and van Ours, 2008, 2009). Seen from this perspective, arrangements such as telehomework and especially flexi-time are suitable alternatives for part-time work in providing employees with more temporal and locational flexibility. 


\section{References}

Akerlof, G. A., A. K. Rose and J. L. Yellen (1988). 'Job switching and job satisfaction in the U.S. labor market'. Brookings Papers on Economic Activity 1988.2, pp. 495-594. URL: http://www.jstor.org/stable/2534536.

Argyle, M. (1989). 'Do happy workers work harder? The effect of job satisfaction on work performance'. In: How harmful is happiness? consequences of enjoying life or not. Ed. by R. Veenhoven. Rotterdam: Universitaire Pers Rotterdam, pp. 94-105.

Asadullah, N. and R. M. Fernández (2008). Work-life balance practices and the gender gap in job satisfaction in the UK: Evidence from matched employer-employee data. IZA Discussion Paper 3582. Bonn: Institute for the Study of Labor (IZA). URL: http://ftp. iza.org/dp3582.pdf.

Baetschmann, G., K. Staub and R. Winkelmann (2011). Consistent estimation of the fixed effects ordered logit model. IZA Discussion Paper 5443. Bonn: Institute for the Study of Labor (IZA). URL: http://ftp.iza.org/dp5443.pdf.

Bailey, D. E. and N. B. Kurland (2002). 'A review of telework research: findings, new directions, and lessons for the study of modern work'. Journal of Organizational Behavior 23.4, pp. 383-400. DoI: $10.1002 /$ job.144.

Baltes, B. B. et al. (1999). 'Flexible and compressed workweek schedules: a meta-analysis of their effects on work-related criteria'. Journal of Applied Psychology 84.4, pp. 496513. DoI: $10.1037 / 0021-9010.84 .4 .496$.

Bender, K. A., S. M. Donohue and J. S. Heywood (2005). 'Job satisfaction and gender segregation'. Oxford Economic Papers 57.3, pp. 479-496. Dor: 10.1093/oep/gpi015.

BMFSFJ (2012). Zeit für Familie. Familienzeitpolitik als Chance einer nachhaltigen Familienpolitik. Achter Familienbericht. Bericht der Sachverständigenkommission. Berlin: Bundesministerium für Familie, Senioren, Frauen und Jugend. URL: http://www.bmfsfj. de/RedaktionBMFSFJ/Abteilung2/Pdf-Anlagen/Achter-familienbericht.pdf.

Böckerman, P. and P. Ilmakunnas (2012). 'The job satisfaction-productivity nexus: A study using matched survey and register data'. ILRReview 65.2, pp. 244-262. URL: http://digitalcommons.ilr.cornell.edu/ilrreview/vol65/iss2/3.

Booth, A. L. and J. C. van Ours (2008). 'Job satisfaction and family happiness: The part-time work puzzle'. The Economic Journal 118.526, F77-F99. DoI: 10.1111/j.1468-0297. 2007.02117.x.

Booth, A. L. and J. C. van Ours (2009). 'Hours of work and gender identity: Does part-time work make the family happier?' Economica 76.301, pp. 176-196. DoI: 10.1111/j.14680335.2007.00670.x.

Booth, A. L. and J. C. van Ours (2013). 'Part-time jobs: What women want?' Journal of Population Economics 26.1, pp. 263-283. DoI: 10.1007/s00148-012-0417-9.

Borjas, G. J. (1979). 'Job satisfaction, wages, and unions'. The Journal of Human Resources 14.1, pp. 21-40. URL: http://www.jstor.org/stable/145536. 
Bosch, G. (1999). 'Working time: tendencies and emerging issues'. International Labour Review 138.2, pp. 131-149. DoI: 10.1111/j.1564-913X.1999.tb00063.x.

Casper, W. J. and C. M. Harris (2008). 'Work-life benefits and organizational attachment: Self-interest utility and signaling theory models'. Journal of Vocational Behavior 72.1, pp. 95-109. DoI: 10.1016/j.jvb.2007.10.015.

CEA (2010). Work-life balance and the economics of workplace flexibility. Washington, D.C.: Executive Office of the President - Council of Economic Advisers. URL: http : //www.wh.gov/files/documents/100331-cea-economics-workplace-flexibility.pdf.

Chung, H. (2009). Flexibility for whom? Working time flexibility practices of European companies. Tilburg: Tilburg University. URL: http://arno.uvt.nl/show.cgi?fid=100156.

Clark, A. E. (1996). 'Job satisfaction in Britain'. British Journal of Industrial Relations 34.2, pp. 189-217. DoI: 10.1111/j.1467-8543.1996.tb00648.x.

Clark, A. E. (1997). 'Job satisfaction and gender: Why are women so happy at work?' Labour Economics 4.4, pp. 341-372. DoI: 10.1016/S0927-5371(97)00010-9.

Clark, A. E. (2001). 'What really matters in a job? Hedonic measurement using quit data'. Labour Economics 8.2, pp. 223-242. DoI: 10.1016/S0927-5371(01)00031-8.

Clark, A. E. and A. J. Oswald (1996). 'Satisfaction and comparison income'. Journal of Public Economics 61.3, pp. 359-381. DOI: 10.1016/0047-2727(95)01564-7.

Connolly, S. and M. Gregory (2008). 'Moving down: Women's part-time work and occupational change in Britain 1991-2001'. The Economic Journal 118.526, F52-F76. DoI: 10.1111/j.1468-0297.2007.02116.x.

Cotti, C. D., M. R. Haley and L. A. Miller (2013). 'Workplace flexibilities, job satisfaction and union membership in the US workforce'. British Journal of Industrial Relations Early View. DoI: $10.1111 /$ bjir.12025.

Cousins, C. R. and N. Tang (2004). 'Working time and work and family conflict in the Netherlands, Sweden and the UK'. Work Employment Society 18.3, pp. 531-549. DoI: 10.1177/0950017004045549.

Dalton, A. H. and J. G. Marcis (1987). 'Gender differences in job satisfaction among young adults'. Journal of Behavioral Economics 16.1, pp. 21-32. DoI: 10.1016/0090-5720(87) 90003-9.

Dickerson, A., A. R. Hole and L. Munford (2012). The relationship between well-being and commuting re-visited: Does the choice of methodology matter? Working Paper 2012016. The University of Sheffield, Department of Economics. URL: http://eprints.whiterose. ac.uk/74397/1/serps_2012016.pdf.

Diener, E. (1984). 'Subjective well-being'. Psychological Bulletin 95.3, pp. 542-575. DoI: 10.1037/0033-2909.95.3.542.

Fagan, C. (2004). 'Gender and working time in industrialized countries'. In: Working time and workers' preferences in industrialized countries. Finding the balance. Ed. by J. C. Messenger. Routledge, pp. 108-146. 
Faragher, E. B., M. Cass and C. L. Cooper (2005). 'The relationship between job satisfaction and health: A meta-analysis'. Occupational and Environmental Medicine 62.2, pp. 105112. URL: http://www.jstor.org/stable/27732461.

Ferrer-i-Carbonell, A. and P. Frijters (2004). 'How important is methodology for the estimates of the determinants of happiness?' The Economic Journal 114.497, pp. 641659. DoI: 10.1111/j.1468-0297.2004.00235.x.

Fischer, J. A. and A. Sousa-Poza (2009). 'Does job satisfaction improve the health of workers? New evidence using panel data and objective measures of health'. Health Economics 18.1, pp. 71-89. DoI: 10.1002/hec.1341.

Freeman, R. B. (1978). 'Job satisfaction as an economic variable'. The American Economic Review 68.2, pp. 135-141. uRL: http://www.jstor.org/stable/1816677.

Freeman, R. B. (1998). 'War of the models: Which labour market institutions for the 21st century?' Labour Economics 5.1, pp. 1-24. DoI: 10.1016/S0927-5371(98)00002-5.

Frey, B. S. and A. Stutzer (2002). 'What can economists learn from happiness research?' Journal of Economic Literature 40.2, pp. 402-435. URL: http://www.jstor.org/stable/ 2698383.

Frijters, P. and T. Beatton (2012). 'The mystery of the U-shaped relationship between happiness and age'. Journal of Economic Behavior \& Organization 82.2, pp. 525-542. DoI: $10.1016 /$ j.jebo.2012.03.008.

Gajendran, R. S. and D. A. Harrison (2007). 'The good, the bad, and the unknown about telecommuting: Meta-analysis of psychological mediators and individual consequences'. The Journal of Applied Psychology 92.6, pp. 1524-1541. DoI: 10.1037/0021-9010.92.6. 1524

Geishecker, I., M. Riedl and P. Frijters (2012). 'Offshoring and job loss fears: An econometric analysis of individual perceptions'. Labour Economics 19.5, pp. 738-747. DoI: 10.1016/ j.labeco.2012.05.018.

Golden, T. D. (2006). 'The role of relationships in understanding telecommuter satisfaction'. Journal of Organizational Behavior 27.3, pp. 319-340. DoI: 10.1002/job.369.

Golden, T. D. and J. F. Veiga (2005). 'The impact of extent of telecommuting on job satisfaction: Resolving inconsistent findings'. Journal of Management 31.2, pp. 301-318. DoI: $10.1177 / 0149206304271768$.

Grover, S. L. and K. J. Crooker (1995). 'Who appreciates family-responsive human resource policies: The impact of family-friendly policies on the organizational attachment of parents and non-parents'. Personnel Psychology 48.2, pp. 271-288. DoI: 10.1111/j.17446570.1995.tb01757.x.

Hamermesh, D. S. (1977). 'Economic aspects of job satisfaction'. In: Essays in labour market analysis. Ed. by O. C. Ashenfelter and W. E. Oates. New York: John Wiley \& Sons, pp. 5372. 
Hill, E. J. et al. (2001). 'Finding an extra day a week: The positive influence of perceived job flexibility on work and family life balance'. Family Relations 50.1, pp. 49-58. DoI: 10.1111/j.1741-3729.2001.00049.x.

Hill, E. J. et al. (2008). 'Defining and conceptualizing workplace flexibility'. Community, Work \& Family 11.2, pp. 149-163. Dor: 10.1080/13668800802024678.

Hinds, P. J. and D. E. Bailey (2003). 'Out of sight, out of sync: Understanding conflict in distributed teams'. Organization Science 14.6, pp. 615-632. DoI: 10.1287/orsc.14.6. 615.24872 .

Hulin, C. L., M. Roznowski and D. Hachiya (1985). 'Alternative opportunities and withdrawal decisions: Empirical and theoretical discrepancies and an integration'. Psychological Bulletin 97.2, pp. 233-250. DoI: 10.1037/0033-2909.97.2.233.

Jonge, J. et al. (2001). 'Testing reciprocal relationships between job characteristics and psychological well-being: A cross-lagged structural equation model'. Journal of Occupational and Organizational Psychology 74.1, pp. 29-46. DoI: 10.1348 / 096317901167217.

Judge, T. A. and S. Watanabe (1993). 'Another look at the job satisfaction-life satisfaction relationship'. Journal of Applied Psychology 78.6, pp. 939-948. DoI: 10.1037/00219010.78.6.939.

Judge, T. A. et al. (2001). 'The job satisfaction-job performance relationship: A qualitative and quantitative review'. Psychological Bulletin 127.3, pp. 376-407. DoI: 10.1037/00332909.127.3.376.

Kalleberg, A. L. (1977). 'Work values and job rewards: A theory of job satisfaction'. American Sociological Review 42.1, pp. 124-143. URL: http : / / www. jstor. org/ stable / 2117735.

Kalleberg, A. L., J. Reynolds and P. V. Marsden (2003). 'Externalizing employment: Flexible staffing arrangements in US organizations'. Social Science Research 32.4, pp. 525-552. DoI: $10.1016 /$ S0049-089X(03)00013-9.

Kelliher, C. and D. Anderson (2010). 'Doing more with less? Flexible working practices and the intensification of work'. Human Relations 63.1, pp. 83-106. DoI: 10.1177/ 0018726709349199.

Kossek, E. E., B. A. Lautsch and S. C. Eaton (2006). 'Telecommuting, control, and boundary management: Correlates of policy use and practice, job control, and work-family effectiveness'. Journal of Vocational Behavior 68.2, pp. 347-367. DoI: 10.1016/j.jvb. 2005.07.002.

Kristensen, N. and N. Westergaard-Nielsen (2007). 'Reliability of job satisfaction measures'. Journal of Happiness Studies 8.2, pp. 273-292. DoI: 10.1007/s10902-006-9027-0.

Manning, A. (2003). 'The real thin theory: Monopsony in modern labour markets'. Labour Economics 10.2, pp. 105-131. DoI: 10.1016/S0927-5371(03)00018-6.

Manning, A. and B. Petrongolo (2008). 'The part-time pay penalty for women in Britain'. Economic Journal 118.526, F28-F51. DoI: 10.1111/j.1468-0297.2007.02115.x. 
Mukherjee, B. et al. (2008). 'Fitting stratified proportional odds models by amalgamating conditional likelihoods'. Statistics in Medicine 27.24, pp. 4950-4971. DoI: 10.1002/sim. 3325

Ostroff, C. (1992). 'The relationship between satisfaction, attitudes, and performance: An organizational level analysis'. Journal of Applied Psychology 77.6, pp. 963-974. DoI: 10.1037/0021-9010.77.6.963.

Parent-Thirion, A. et al. (2007). Fourth European Working Conditions Survey. Eurofound report. Luxembourg: Office for Official Publications of the European Communities. URL: http://www.eurofound.europa.eu/pubdocs/2006/98/en/2/ef0698en.pdf.

Peters, P., L. den Dulk and T. van der Lippe (2009). 'The effects of time-spatial flexibility and new working conditions on employees' work-life balance: The Dutch case'. Community, Work \& Family 12.3, pp. 279-297. DoI: 10.1080/13668800902968907.

Peters, P. and T. van der Lippe (2007). "The time-pressure reducing potential of telehomeworking: The Dutch case'. The International Journal of Human Resource Management 18.3, pp. 430-447. DoI: 10.1080/09585190601167730.

Plantenga, J. (2002). 'Combining work and care in the polder model: An assessment of the Dutch part-time strategy'. Critical Social Policy 22.1, pp. 53-71. Dor: 10.1177 / 02610183020220010601.

Plantenga, J. (2003). 'Changing work and life patterns: Examples of new working-time arrangements in the European member states'. In: Changing life patterns in western industrial societies. Ed. by J. Z. Giele and E. Holst. Oxford: Elsevier, pp. 119-135. DoI: 10.1016/S1040-2608(03)08006-7.

Portegijs, W. and S. Keuzenkamp, eds. (2008). Nederland deeltijdland. Vrouwen en deeltijdwerk. Den Haag: Sociaal en Cultureel Planbureau. URL: http://www.scp.nl/dsresource? objectid $=19663$.

Riedl, M. and I. Geishecker (2012). Ordered response models and non-random personality traits: Monte Carlo simulations and a practical guide. cege Discussion Paper 116. Göttingen: Georg-August-Universität Göttingen. URL: http://hdl.handle.net/10419/70220.

Roelen, C. A. M. et al. (2008). 'Job satisfaction and sickness absence: A questionnaire survey'. Occupational Medicine 58.8, pp. 567-571. DoI: 10.1093/occmed/kqn113.

Román, A. (2006). Deviating from the standard: Effects on labor continuity and career patterns. Amsterdam: Dutch University Press. URL: http://dspace.library.uu.nl/handle/ $1874 / 13475$.

Russo, G. and W. Hassink (2008). 'The part-time wage gap: A career perspective'. De Economist 156.2, pp. 145-174. DoI: 10.1007/s10645-008-9087-0.

Saltzstein, A. L., Y. Ting and G. H. Saltzstein (2001). 'Work-family balance and job satisfaction: The impact of family-friendly policies on attitudes of federal government employees'. Public Administration Review 61.4, pp. 452-467. Dor: 10.1111/ 0033 3352.00049 . 
Sandor, E. (2011). European Company Survey 2009. Part-time work in Europe. Eurofound report. Luxembourg: Publications Office of the European Union. URL: http://www. eurofound.europa.eu/pubdocs/2010/86/en/2/EF1086EN.pdf.

Scandura, T. A. and M. J. Lankau (1997). 'Relationships of gender, family responsibility and flexible work hours to organizational commitment and job satisfaction'. Journal of Organizational Behavior 18.4, pp. 377-391. URL: http://www.jstor.org/stable/ 3100183.

Sloane, P. J. and H. Williams (2000). 'Job satisfaction, comparison earnings, and gender'. LABOUR 14.3, pp. 473-502. DOI: 10.1111/1467-9914.00142.

Sociaal-Economische Raad (2011). Tijden van de samenleving: Slimmer organiseren van tijd en plaats van arbeid en dienstverlening. Advice 2011/06. Den Haag: SociaalEconomische Raad. URL: http://www.ser.nl/ /media/DB_Adviezen/2010_2019/ 2011/b29686.ashx.

Sousa-Poza, A. and A. A. Sousa-Poza (2000a). 'Taking another look at the gender/jobsatisfaction paradox'. Kyklos 53.2, pp. 135-152. DoI: 10.1111/1467-6435.00114.

Sousa-Poza, A. and A. A. Sousa-Poza (2000b). 'Well-being at work: A cross-national analysis of the levels and determinants of job satisfaction'. Journal of Socio-Economics 29.6, pp. 517-538. DoI: 10.1016/S1053-5357(00)00085-8.

StataCorp (2013). 'Suest'. In: Stata Base Reference Manual. Release 13. College Station, TX: Stata Press, pp. 2237-2254.

Ten Brummelhuis, L. L., J. M. Haar and T. van der Lippe (2010). 'Collegiality under pressure: The effects of family demands and flexible work arrangements in the Netherlands'. The International Journal of Human Resource Management 21.15, pp. 2831-2847. DoI: 10.1080/09585192.2010.528666.

Virick, M., N. DaSilva and K. Arrington (2010). 'Moderators of the curvilinear relation between extent of telecommuting and job and life satisfaction: The role of performance outcome orientation and worker type'. Human Relations 63.1, pp. 137-154. Dor: 10. $1177 / 0018726709349198$.

Visser, J. (2002). 'The first part-time economy in the world: A model to be followed?' Journal of European Social Policy 12.1, pp. 23-42. Dor: 10 . 1177 / 0952872002012001561.

Weesie, J. (1999). 'Seemingly unrelated estimation and the cluster-adjusted sandwich estimator'. Stata Technical Bulletin 52, pp. 34-74. URL: http : / / www. stata.com / products/stb/journals/stb52.pdf.

Zelenski, J. M., S. A. Murphy and D. A. Jenkins (2008). 'The happy-productive worker thesis revisited'. Journal of Happiness Studies 9.4, pp. 521-537. DoI: 10.1007/s10902-0089087-4. 


\section{Tables}

Table 8: TLF arrangements on working-time fit

\begin{tabular}{|c|c|c|c|c|c|c|}
\hline & \multicolumn{2}{|c|}{ Total } & \multicolumn{2}{|c|}{ Male } & \multicolumn{2}{|c|}{ Female } \\
\hline & Linear FE & $\mathrm{BUC}(\mathrm{OR})$ & Linear FE & BUC (OR) & Linear FE & BUC (OR) \\
\hline Flexi-time & $\begin{array}{l}0.205^{* * *} \\
(0.031)\end{array}$ & $\begin{array}{l}1.798^{* * *} \\
(0.160)\end{array}$ & $\begin{array}{l}0.185^{* * *} \\
(0.044)\end{array}$ & $\begin{array}{l}1.639 * * * \\
(0.193)\end{array}$ & $\begin{array}{l}0.224^{* * *} \\
(0.045)\end{array}$ & $\begin{array}{l}1.973^{* * *} \\
(0.273)\end{array}$ \\
\hline Telehomework & $\begin{array}{l}-0.028 \\
(0.036)\end{array}$ & $\begin{array}{c}0.911 \\
(0.092)\end{array}$ & $\begin{array}{l}-0.043 \\
(0.049)\end{array}$ & $\begin{array}{c}0.890 \\
(0.121)\end{array}$ & $\begin{array}{l}-0.005 \\
(0.054)\end{array}$ & $\begin{array}{c}0.936 \\
(0.142)\end{array}$ \\
\hline $\begin{array}{l}\text { Part-time work } \\
\text { Ref: Full-time }(36 \mathrm{~h}+)\end{array}$ & & & & & & \\
\hline Small part-time $(1-11 \mathrm{~h})$ & $\begin{array}{l}0.308^{* * *} \\
(0.114)\end{array}$ & $\begin{array}{l}2.275^{* * *} \\
(0.712)\end{array}$ & $\begin{array}{c}0.206 \\
(0.324)\end{array}$ & $\begin{array}{c}1.586 \\
(1.241)\end{array}$ & $\begin{array}{c}0.295^{* *} \\
(0.131)\end{array}$ & $\begin{array}{c}2.358^{* *} \\
(0.874)\end{array}$ \\
\hline Medium part-time $(12-19 \mathrm{~h})$ & $\begin{array}{l}0.283^{* * *} \\
(0.082)\end{array}$ & $\begin{array}{l}1.973^{* * *} \\
(0.401)\end{array}$ & $\begin{array}{l}0.578^{* *} \\
(0.254)\end{array}$ & $\begin{array}{l}3.278^{* *} \\
(1.729)\end{array}$ & $\begin{array}{l}0.268^{* * *} \\
(0.100)\end{array}$ & $\begin{array}{l}1.899^{* *} \\
(0.480)\end{array}$ \\
\hline Large part-time (20-35h) & $\begin{array}{l}0.116^{* *} \\
(0.052)\end{array}$ & $\begin{array}{l}1.326^{* *} \\
(0.184)\end{array}$ & $\begin{array}{c}0.044 \\
(0.071)\end{array}$ & $\begin{array}{c}1.086 \\
(0.225)\end{array}$ & $\begin{array}{c}0.158^{* *} \\
(0.075)\end{array}$ & $\begin{array}{l}1.511^{* *} \\
(0.296)\end{array}$ \\
\hline $\begin{array}{r}\text { Martial status } \\
\text { Ref: Married }\end{array}$ & & & & & & \\
\hline Cohabiting & $\begin{array}{r}0.146^{*} \\
(0.075)\end{array}$ & $\begin{array}{r}1.435^{*} \\
(0.286)\end{array}$ & $\begin{array}{c}0.114 \\
(0.098)\end{array}$ & $\begin{array}{c}1.394 \\
(0.397)\end{array}$ & $\begin{array}{c}0.164 \\
(0.108)\end{array}$ & $\begin{array}{c}1.443 \\
(0.401)\end{array}$ \\
\hline Single & $\begin{array}{l}0.337^{* * *} \\
(0.102)\end{array}$ & $\begin{array}{l}2.393^{* * *} \\
(0.650)\end{array}$ & $\begin{array}{l}0.539^{* * *} \\
(0.165)\end{array}$ & $\begin{array}{l}4.756^{* * *} \\
(2.290)\end{array}$ & $\begin{array}{c}0.227^{*} \\
(0.128)\end{array}$ & $\begin{array}{c}1.619 \\
(0.501)\end{array}$ \\
\hline Child(ren) & $\begin{array}{l}-0.112^{* *} \\
(0.045)\end{array}$ & $\begin{array}{l}0.732^{* *} \\
(0.093)\end{array}$ & $\begin{array}{l}-0.098 \\
(0.062)\end{array}$ & $\begin{array}{c}0.791 \\
(0.135)\end{array}$ & $\begin{array}{l}-0.130^{* *} \\
(0.065)\end{array}$ & $\begin{array}{c}0.657^{* *} \\
(0.123)\end{array}$ \\
\hline $\begin{array}{l}\text { Education } \\
\text { Ref: Primary School }\end{array}$ & & & & & & \\
\hline Lower secondary & $\begin{array}{c}0.038 \\
(0.106)\end{array}$ & $\begin{array}{l}1.054 \\
(0.299)\end{array}$ & $\begin{array}{l}-0.016 \\
(0.138)\end{array}$ & $\begin{array}{c}0.931 \\
(0.318)\end{array}$ & $\begin{array}{c}0.178 \\
(0.152)\end{array}$ & $\begin{array}{l}1.597 \\
(0.855)\end{array}$ \\
\hline Higher secondary & $\begin{array}{c}0.088 \\
(0.111)\end{array}$ & $\begin{array}{l}1.204 \\
(0.358)\end{array}$ & $\begin{array}{c}0.020 \\
(0.148)\end{array}$ & $\begin{array}{c}1.022 \\
(0.373)\end{array}$ & $\begin{array}{c}0.232 \\
(0.158)\end{array}$ & $\begin{array}{c}1.842 \\
(0.981)\end{array}$ \\
\hline Vocational college & $\begin{array}{c}0.047 \\
(0.123)\end{array}$ & $\begin{array}{c}1.110 \\
(0.366)\end{array}$ & $\begin{array}{l}-0.051 \\
(0.165)\end{array}$ & $\begin{array}{c}0.850 \\
(0.354)\end{array}$ & $\begin{array}{c}0.238 \\
(0.175)\end{array}$ & $\begin{array}{c}1.952 \\
(1.117)\end{array}$ \\
\hline Academic & $\begin{array}{c}0.121 \\
(0.149)\end{array}$ & $\begin{array}{c}1.335 \\
(0.536)\end{array}$ & $\begin{array}{c}0.093 \\
(0.189)\end{array}$ & $\begin{array}{c}1.259 \\
(0.629)\end{array}$ & $\begin{array}{c}0.187 \\
(0.236)\end{array}$ & $\begin{array}{c}1.762 \\
(1.202)\end{array}$ \\
\hline Work experience & $\begin{array}{l}-0.002 \\
(0.004)\end{array}$ & $\begin{array}{c}0.997 \\
(0.010)\end{array}$ & $\begin{array}{c}0.001 \\
(0.006)\end{array}$ & $\begin{array}{c}1.005 \\
(0.014)\end{array}$ & $\begin{array}{l}-0.004 \\
(0.006)\end{array}$ & $\begin{array}{c}0.989 \\
(0.015)\end{array}$ \\
\hline Wage per hour & $\begin{array}{c}-0.001 \\
(0.003)\end{array}$ & $\begin{array}{c}0.996 \\
(0.010)\end{array}$ & $\begin{array}{l}-0.003 \\
(0.005)\end{array}$ & $\begin{array}{c}0.993 \\
(0.013)\end{array}$ & $\begin{array}{c}0.003 \\
(0.005)\end{array}$ & $\begin{array}{c}1.007 \\
(0.017)\end{array}$ \\
\hline Permanent contract & $\begin{array}{c}-0.037 \\
(0.047)\end{array}$ & $\begin{array}{c}0.886 \\
(0.108)\end{array}$ & $\begin{array}{l}-0.059 \\
(0.076)\end{array}$ & $\begin{array}{c}0.890 \\
(0.159)\end{array}$ & $\begin{array}{l}-0.013 \\
(0.059)\end{array}$ & $\begin{array}{c}0.894 \\
(0.150)\end{array}$ \\
\hline Supervisor & $\begin{array}{c}0.000 \\
(0.035)\end{array}$ & $\begin{array}{c}1.009 \\
(0.094)\end{array}$ & $\begin{array}{c}-0.001 \\
(0.047)\end{array}$ & $\begin{array}{c}1.004 \\
(0.128)\end{array}$ & $\begin{array}{c}0.006 \\
(0.053)\end{array}$ & $\begin{array}{c}1.020 \\
(0.141)\end{array}$ \\
\hline 2nd job & $-0.113^{*}$ & $0.734^{*}$ & -0.064 & 0.764 & $-0.144^{*}$ & $0.688^{*}$ \\
\hline
\end{tabular}


Table 8: TLF arrangements on working-time fit (cont.)

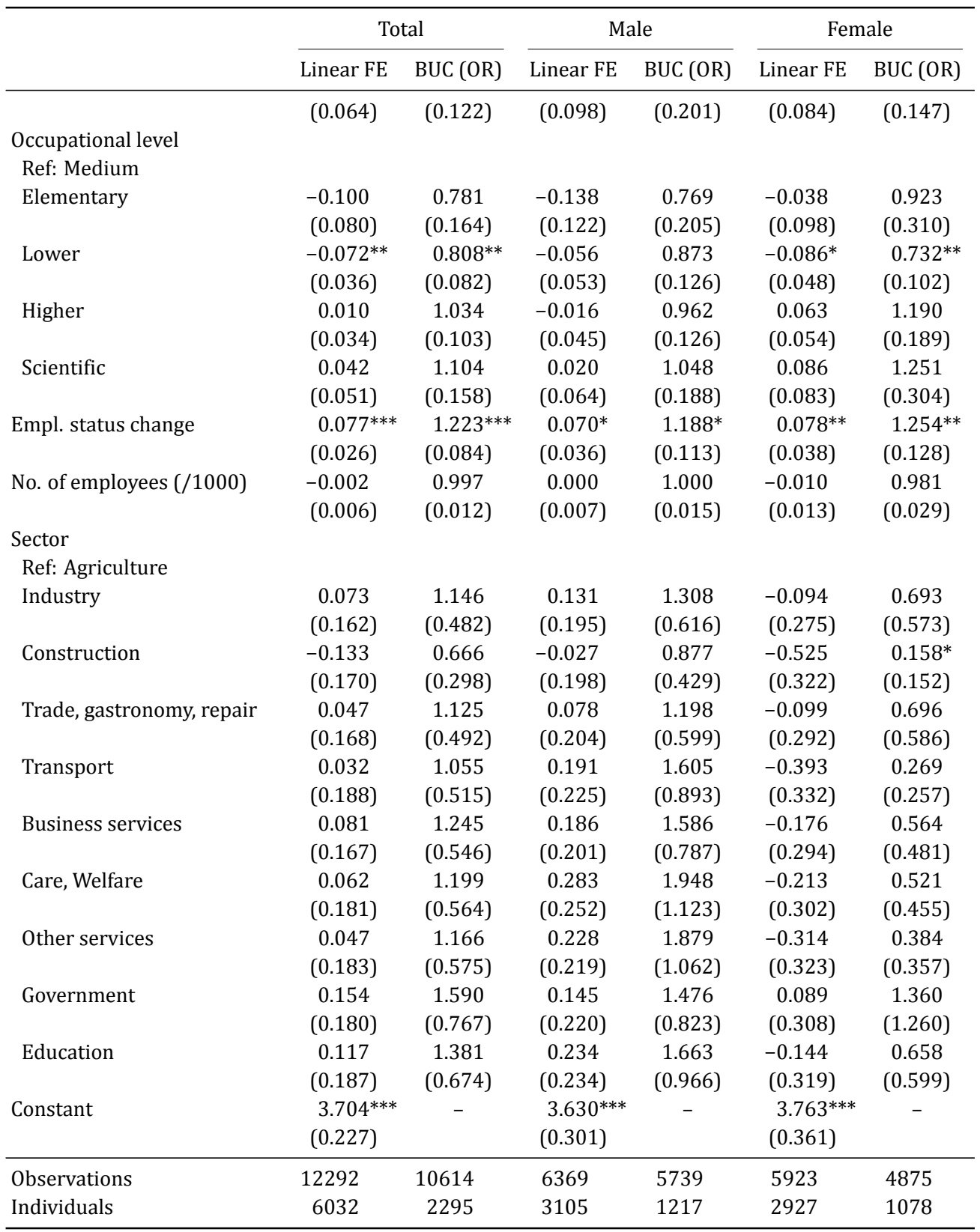

${ }^{*} p<0.10,{ }^{* *} p<0.05,{ }^{* * *} p<0.01$

Note: Parameter estimates of TLF arrangements on working-time fit. BUC coefficients are odds-ratios; the reference point is therefore one. Year (wave) dummies included. Clustered standard errors in parentheses. 
Table 9: TLF arrangements on job satisfaction

\begin{tabular}{|c|c|c|c|c|c|c|}
\hline & \multicolumn{2}{|c|}{ Total } & \multicolumn{2}{|c|}{ Male } & \multicolumn{2}{|c|}{ Female } \\
\hline & Linear FE & BUC (OR) & Linear FE & BUC (OR) & Linear FE & BUC (OR) \\
\hline Flexi-time & $\begin{array}{l}0.087^{* * *} \\
(0.023)\end{array}$ & $\begin{array}{l}1.505^{* * *} \\
(0.148)\end{array}$ & $\begin{array}{l}0.084^{* * *} \\
(0.030)\end{array}$ & $\begin{array}{l}1.528^{* * *} \\
(0.204)\end{array}$ & $\begin{array}{l}0.095^{* * *} \\
(0.035)\end{array}$ & $\begin{array}{l}1.581^{* * *} \\
(0.233)\end{array}$ \\
\hline Telehomework & $\begin{array}{l}0.061^{* *} \\
(0.025)\end{array}$ & $\begin{array}{l}1.326^{* *} \\
(0.153)\end{array}$ & $\begin{array}{l}0.082^{* *} \\
(0.035)\end{array}$ & $\begin{array}{l}1.469^{* *} \\
(0.245)\end{array}$ & $\begin{array}{c}0.043 \\
(0.035)\end{array}$ & $\begin{array}{c}1.172 \\
(0.188)\end{array}$ \\
\hline $\begin{array}{l}\text { Part-time work } \\
\text { Ref: Full-time }(36+h)\end{array}$ & & & & & & \\
\hline Small part-time $(1-11 \mathrm{~h})$ & $\begin{array}{l}-0.168^{* *} \\
(0.084)\end{array}$ & $\begin{array}{c}0.586 \\
(0.222)\end{array}$ & $\begin{array}{l}-0.149 \\
(0.234)\end{array}$ & $\begin{array}{c}0.581 \\
(0.706)\end{array}$ & $\begin{array}{l}-0.200^{* *} \\
(0.096)\end{array}$ & $\begin{array}{c}0.504 \\
(0.210)\end{array}$ \\
\hline Medium part-time $(12-19 \mathrm{~h})$ & $\begin{array}{l}-0.132^{* *} \\
(0.057)\end{array}$ & $\begin{array}{r}0.642^{*} \\
(0.147)\end{array}$ & $\begin{array}{c}0.054 \\
(0.162)\end{array}$ & $\begin{array}{c}1.458 \\
(0.990)\end{array}$ & $\begin{array}{l}-0.194^{* * *} \\
(0.072)\end{array}$ & $\begin{array}{c}0.499^{* *} \\
(0.142)\end{array}$ \\
\hline Large part-time (20-35h) & $\begin{array}{l}-0.072^{* *} \\
(0.036)\end{array}$ & $\begin{array}{r}0.779^{*} \\
(0.118)\end{array}$ & $\begin{array}{l}-0.045 \\
(0.049)\end{array}$ & $\begin{array}{c}0.842 \\
(0.205)\end{array}$ & $\begin{array}{l}-0.117^{* *} \\
(0.054)\end{array}$ & $\begin{array}{r}0.682^{*} \\
(0.142)\end{array}$ \\
\hline $\begin{array}{l}\text { Martial status } \\
\text { Ref: Married }\end{array}$ & & & & & & \\
\hline Cohabiting & $\begin{array}{l}-0.035 \\
(0.046)\end{array}$ & $\begin{array}{c}0.891 \\
(0.183)\end{array}$ & $\begin{array}{l}-0.071 \\
(0.064)\end{array}$ & $\begin{array}{c}0.799 \\
(0.260)\end{array}$ & $\begin{array}{l}-0.003 \\
(0.065)\end{array}$ & $\begin{array}{c}0.973 \\
(0.261)\end{array}$ \\
\hline Single & $\begin{array}{c}0.056 \\
(0.061)\end{array}$ & $\begin{array}{c}1.355 \\
(0.396)\end{array}$ & $\begin{array}{c}0.124 \\
(0.089)\end{array}$ & $\begin{array}{c}2.079 \\
(0.996)\end{array}$ & $\begin{array}{c}0.016 \\
(0.081)\end{array}$ & $\begin{array}{c}1.002 \\
(0.363)\end{array}$ \\
\hline Child(ren) & $\begin{array}{c}0.017 \\
(0.028)\end{array}$ & $\begin{array}{c}1.111 \\
(0.154)\end{array}$ & $\begin{array}{l}-0.009 \\
(0.038)\end{array}$ & $\begin{array}{c}1.006 \\
(0.203)\end{array}$ & $\begin{array}{c}0.049 \\
(0.042)\end{array}$ & $\begin{array}{c}1.239 \\
(0.257)\end{array}$ \\
\hline $\begin{array}{l}\text { Education } \\
\text { Ref: Primary School }\end{array}$ & & & & & & \\
\hline Lower secondary & $\begin{array}{l}-0.072 \\
(0.076)\end{array}$ & $\begin{array}{c}0.674 \\
(0.272)\end{array}$ & $\begin{array}{l}-0.142 \\
(0.093)\end{array}$ & $\begin{array}{c}0.478 \\
(0.251)\end{array}$ & $\begin{array}{c}0.070 \\
(0.127)\end{array}$ & $\begin{array}{c}1.527 \\
(0.939)\end{array}$ \\
\hline Higher secondary & $\begin{array}{l}-0.089 \\
(0.081)\end{array}$ & $\begin{array}{c}0.610 \\
(0.257)\end{array}$ & $\begin{array}{l}-0.143 \\
(0.100)\end{array}$ & $\begin{array}{c}0.450 \\
(0.251)\end{array}$ & $\begin{array}{c}0.031 \\
(0.131)\end{array}$ & $\begin{array}{l}1.247 \\
(0.775)\end{array}$ \\
\hline Vocational college & $\begin{array}{l}-0.103 \\
(0.089)\end{array}$ & $\begin{array}{c}0.573 \\
(0.267)\end{array}$ & $\begin{array}{l}-0.166 \\
(0.113)\end{array}$ & $\begin{array}{c}0.398 \\
(0.248)\end{array}$ & $\begin{array}{c}0.017 \\
(0.142)\end{array}$ & $\begin{array}{c}1.186 \\
(0.822)\end{array}$ \\
\hline Academic & $\begin{array}{l}-0.126 \\
(0.101)\end{array}$ & $\begin{array}{c}0.513 \\
(0.276)\end{array}$ & $\begin{array}{l}-0.179 \\
(0.131)\end{array}$ & $\begin{array}{c}0.366 \\
(0.260)\end{array}$ & $\begin{array}{l}-0.014 \\
(0.158)\end{array}$ & $\begin{array}{l}1.000 \\
(0.837)\end{array}$ \\
\hline Work experience & $\begin{array}{l}-0.004 \\
(0.003)\end{array}$ & $\begin{array}{c}0.983 \\
(0.011)\end{array}$ & $\begin{array}{l}-0.005 \\
(0.004)\end{array}$ & $\begin{array}{c}0.983 \\
(0.015)\end{array}$ & $\begin{array}{l}-0.002 \\
(0.004)\end{array}$ & $\begin{array}{c}0.989 \\
(0.017)\end{array}$ \\
\hline Wage per hour & $\begin{array}{l}0.007^{* * *} \\
(0.002)\end{array}$ & $\begin{array}{l}1.031^{* *} \\
(0.012)\end{array}$ & $\begin{array}{l}0.009^{* * *} \\
(0.003)\end{array}$ & $\begin{array}{l}1.037^{* *} \\
(0.017)\end{array}$ & $\begin{array}{c}0.004 \\
(0.004)\end{array}$ & $\begin{array}{l}1.017 \\
(0.020)\end{array}$ \\
\hline Permanent contract & $\begin{array}{l}-0.062^{*} \\
(0.034)\end{array}$ & $\begin{array}{c}0.826 \\
(0.108)\end{array}$ & $\begin{array}{l}-0.075 \\
(0.053)\end{array}$ & $\begin{array}{c}0.788 \\
(0.152)\end{array}$ & $\begin{array}{l}-0.049 \\
(0.044)\end{array}$ & $\begin{array}{c}0.843 \\
(0.155)\end{array}$ \\
\hline Supervisor & $\begin{array}{l}0.060^{* * *} \\
(0.023)\end{array}$ & $\begin{array}{l}1.299^{* *} \\
(0.140)\end{array}$ & $\begin{array}{c}0.068^{* *} \\
(0.030)\end{array}$ & $\begin{array}{l}1.421^{* *} \\
(0.206)\end{array}$ & $\begin{array}{c}0.052 \\
(0.037)\end{array}$ & $\begin{array}{c}1.179 \\
(0.193)\end{array}$ \\
\hline 2nd job & $\begin{array}{l}-0.095^{* *} \\
(0.044)\end{array}$ & $\begin{array}{c}0.668^{* *} \\
(0.131)\end{array}$ & $\begin{array}{l}-0.024 \\
(0.063)\end{array}$ & $\begin{array}{c}0.887 \\
(0.269)\end{array}$ & $\begin{array}{l}-0.134^{* *} \\
(0.061)\end{array}$ & $\begin{array}{l}0.590^{* *} \\
(0.149)\end{array}$ \\
\hline $\begin{array}{l}\text { Occupational level } \\
\text { Ref: Medium }\end{array}$ & & & & & & \\
\hline Elementary & 0.000 & 1.058 & 0.029 & 1.188 & -0.027 & 0.914 \\
\hline
\end{tabular}


Table 9: TLF arrangements on job satisfaction (cont.)

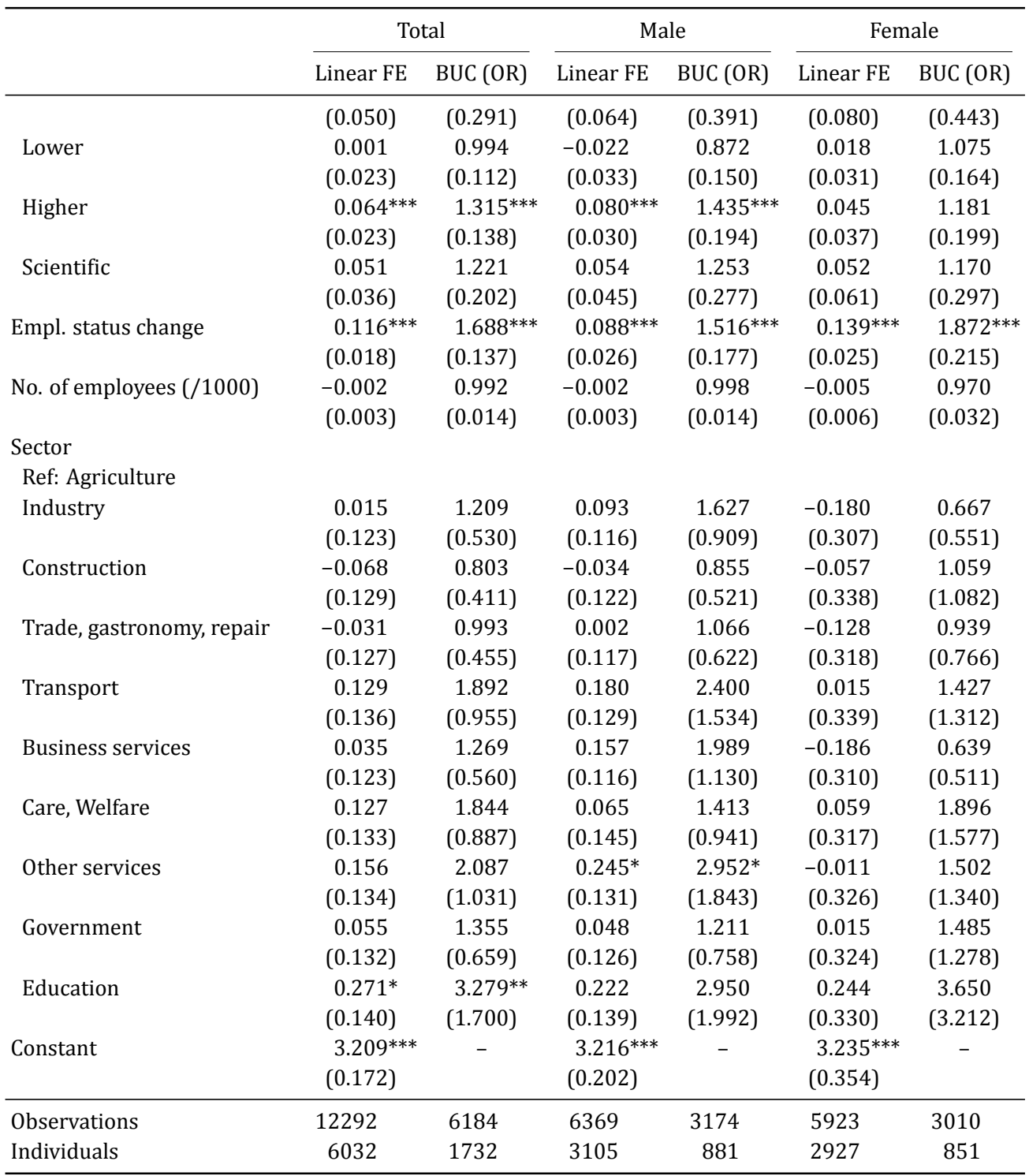

${ }^{*} p<0.10,{ }^{* *} p<0.05,{ }^{* * *} p<0.01$

Note: Parameter estimates of TLF arrangements on job satisfaction. BUC coefficients are odds-ratios; the reference point is therefore one. Year (wave) dummies included. Clustered standard errors in parentheses. 
Table 10: TLF arrangements on working-time fit by children at home

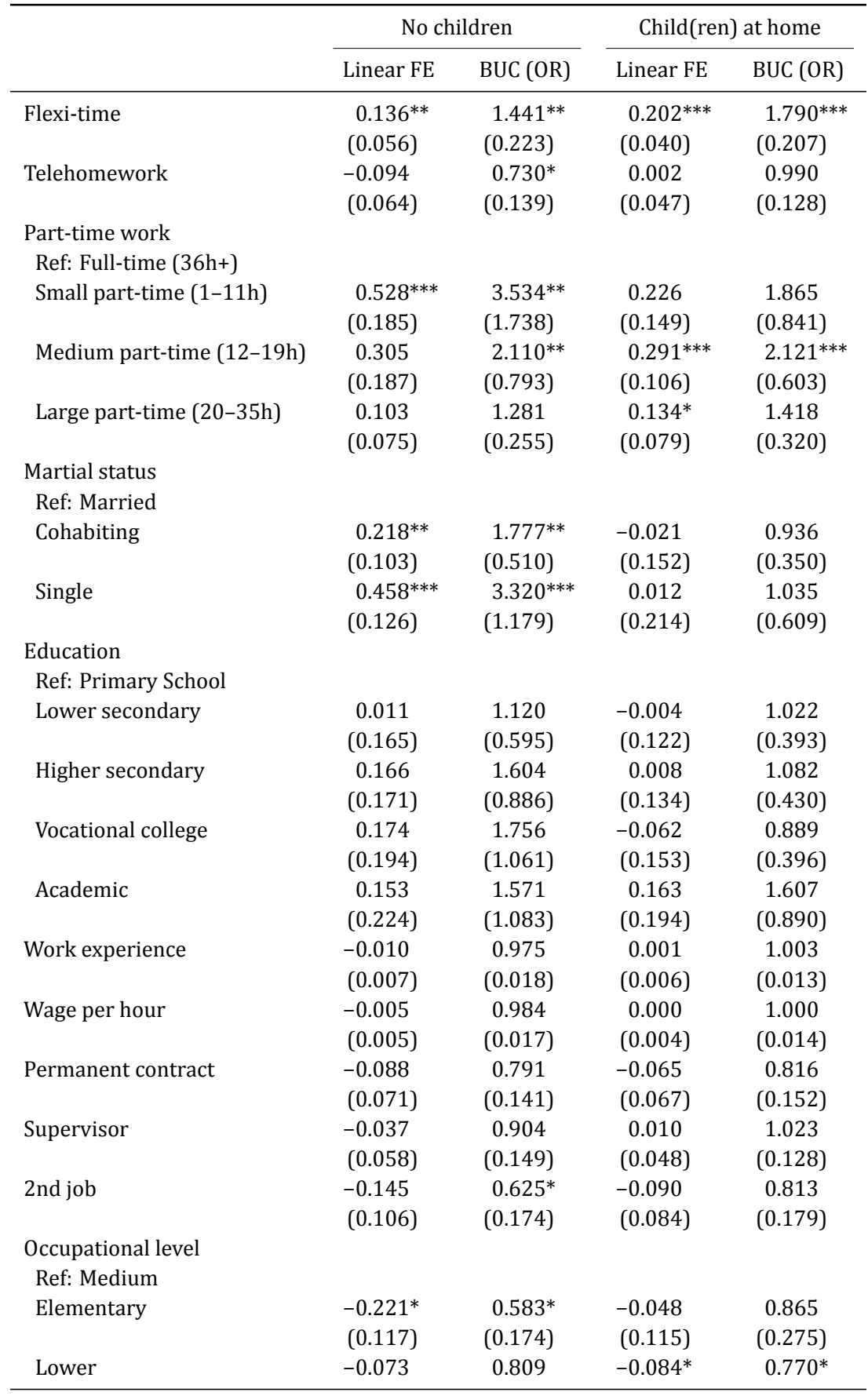


Table 10: TLF arrangements on working-time fit by children at home (cont.)

\begin{tabular}{|c|c|c|c|c|}
\hline & \multicolumn{2}{|c|}{ No children } & \multicolumn{2}{|c|}{ Child(ren) at home } \\
\hline & Linear FE & BUC (OR) & Linear FE & BUC (OR) \\
\hline & $(0.057)$ & $(0.129)$ & $(0.050)$ & $(0.110)$ \\
\hline Higher & $\begin{array}{c}0.071 \\
(0.057)\end{array}$ & $\begin{array}{c}1.217 \\
(0.202)\end{array}$ & $\begin{array}{l}-0.047 \\
(0.044)\end{array}$ & $\begin{array}{c}0.881 \\
(0.113)\end{array}$ \\
\hline Scientific & $\begin{array}{c}0.074 \\
(0.083)\end{array}$ & $\begin{array}{c}1.235 \\
(0.301)\end{array}$ & $\begin{array}{c}0.021 \\
(0.066)\end{array}$ & $\begin{array}{l}1.070 \\
(0.200)\end{array}$ \\
\hline Empl. status change & $\begin{array}{c}0.056 \\
(0.043)\end{array}$ & $\begin{array}{c}1.152 \\
(0.139)\end{array}$ & $\begin{array}{r}0.066^{*} \\
(0.034)\end{array}$ & $\begin{array}{l}1.187^{*} \\
(0.108)\end{array}$ \\
\hline No. of employees (/1000) & $\begin{array}{l}-0.008 \\
(0.007)\end{array}$ & $\begin{array}{c}0.979 \\
(0.020)\end{array}$ & $\begin{array}{c}0.000 \\
(0.009)\end{array}$ & $\begin{array}{c}1.001 \\
(0.018)\end{array}$ \\
\hline $\begin{array}{l}\text { Sector } \\
\text { Ref: Agriculture }\end{array}$ & & & & \\
\hline Industry & $\begin{array}{c}0.263 \\
(0.269)\end{array}$ & $\begin{array}{c}2.359 \\
(1.826)\end{array}$ & $\begin{array}{c}0.117 \\
(0.214)\end{array}$ & $\begin{array}{c}1.243 \\
(0.666)\end{array}$ \\
\hline Construction & $\begin{array}{c}0.090 \\
(0.282)\end{array}$ & $\begin{array}{c}1.263 \\
(1.058)\end{array}$ & $\begin{array}{l}-0.135 \\
(0.231)\end{array}$ & $\begin{array}{c}0.735 \\
(0.407)\end{array}$ \\
\hline Trade, gastronomy, repair & $\begin{array}{c}0.337 \\
(0.283)\end{array}$ & $\begin{array}{c}2.843 \\
(2.248)\end{array}$ & $\begin{array}{c}0.066 \\
(0.219)\end{array}$ & $\begin{array}{c}1.156 \\
(0.640)\end{array}$ \\
\hline Transport & $\begin{array}{c}0.382 \\
(0.298)\end{array}$ & $\begin{array}{c}3.757 \\
(3.320)\end{array}$ & $\begin{array}{c}0.082 \\
(0.250)\end{array}$ & $\begin{array}{c}1.186 \\
(0.733)\end{array}$ \\
\hline Business services & $\begin{array}{c}0.381 \\
(0.273)\end{array}$ & $\begin{array}{c}3.347 \\
(2.618)\end{array}$ & $\begin{array}{c}0.101 \\
(0.223)\end{array}$ & $\begin{array}{c}1.306 \\
(0.738)\end{array}$ \\
\hline Care, Welfare & $\begin{array}{c}0.187 \\
(0.295)\end{array}$ & $\begin{array}{c}2.332 \\
(1.909)\end{array}$ & $\begin{array}{c}0.147 \\
(0.244)\end{array}$ & $\begin{array}{c}1.453 \\
(0.899)\end{array}$ \\
\hline Other services & $\begin{array}{r}0.500^{*} \\
(0.299)\end{array}$ & $\begin{array}{r}4.541^{*} \\
(3.848)\end{array}$ & $\begin{array}{l}-0.089 \\
(0.247)\end{array}$ & $\begin{array}{c}0.699 \\
(0.470)\end{array}$ \\
\hline Government & $\begin{array}{c}0.390 \\
(0.285)\end{array}$ & $\begin{array}{c}3.417 \\
(2.832)\end{array}$ & $\begin{array}{c}0.131 \\
(0.242)\end{array}$ & $\begin{array}{c}1.427 \\
(0.902)\end{array}$ \\
\hline Education & $\begin{array}{c}0.355 \\
(0.312)\end{array}$ & $\begin{array}{c}3.386 \\
(2.875)\end{array}$ & $\begin{array}{c}0.248 \\
(0.246)\end{array}$ & $\begin{array}{c}2.017 \\
(1.296)\end{array}$ \\
\hline Constant & $\begin{array}{l}3.516^{* * *} \\
(0.384)\end{array}$ & - & $\begin{array}{l}3.703^{* * *} \\
(0.291)\end{array}$ & - \\
\hline Observations & 5402 & 3608 & 6890 & 6076 \\
\hline Individuals & 3239 & 898 & 3279 & 1279 \\
\hline
\end{tabular}

${ }^{*} p<0.10,{ }^{* *} p<0.05,{ }^{* * *} p<0.01$

Note: Parameter estimates of TLF arrangements on working-time fit. BUC coefficients are oddsratios; the reference point is therefore one. Year (wave) dummies included. Clustered standard errors in parentheses. 
Table 11: TLF arrangements on job satisfaction by children at home

\begin{tabular}{|c|c|c|c|c|}
\hline & \multicolumn{2}{|c|}{ No children } & \multicolumn{2}{|c|}{ Child(ren) at home } \\
\hline & Linear FE & BUC (OR) & Linear FE & BUC (OR) \\
\hline \multirow[t]{2}{*}{ Flexi-time } & $0.066^{*}$ & $1.379^{*}$ & $0.078^{* * *}$ & $1.452^{* * *}$ \\
\hline & $(0.038)$ & $(0.229)$ & $(0.030)$ & $(0.186)$ \\
\hline \multirow[t]{2}{*}{ Telehomework } & 0.030 & 1.139 & $0.069 * *$ & $1.380^{* *}$ \\
\hline & $(0.042)$ & $(0.234)$ & $(0.034)$ & $(0.215)$ \\
\hline \multicolumn{5}{|l|}{ Part-time work } \\
\hline \multicolumn{5}{|l|}{ Ref: Full-time (36h+) } \\
\hline \multirow[t]{2}{*}{ Small part-time $(1-11 \mathrm{~h})$} & -0.145 & 0.671 & $-0.187^{*}$ & 0.473 \\
\hline & $(0.142)$ & $(0.415)$ & $(0.112)$ & $(0.238)$ \\
\hline \multirow[t]{2}{*}{ Medium part-time $(12-19 \mathrm{~h})$} & -0.148 & 0.636 & -0.117 & 0.620 \\
\hline & $(0.092)$ & $(0.239)$ & $(0.085)$ & $(0.210)$ \\
\hline \multirow[t]{2}{*}{ Large part-time $(20-35 \mathrm{~h})$} & $-0.114^{* *}$ & $0.678^{*}$ & -0.054 & 0.777 \\
\hline & $(0.054)$ & $(0.150)$ & $(0.059)$ & $(0.199)$ \\
\hline \multicolumn{5}{|l|}{ Martial status } \\
\hline \multicolumn{5}{|l|}{ Ref: Married } \\
\hline \multirow[t]{2}{*}{ Cohabiting } & -0.038 & 0.806 & -0.036 & 0.885 \\
\hline & $(0.066)$ & $(0.258)$ & $(0.093)$ & $(0.300)$ \\
\hline \multirow[t]{2}{*}{ Single } & 0.111 & 1.728 & -0.112 & 0.574 \\
\hline & $(0.091)$ & $(0.741)$ & $(0.100)$ & $(0.294)$ \\
\hline \multicolumn{5}{|l|}{ Education } \\
\hline \multicolumn{5}{|l|}{ Ref: Primary School } \\
\hline \multirow[t]{2}{*}{ Lower secondary } & -0.099 & 0.431 & -0.027 & 0.889 \\
\hline & $(0.094)$ & $(0.328)$ & $(0.117)$ & $(0.438)$ \\
\hline \multirow[t]{2}{*}{ Higher secondary } & -0.090 & 0.446 & -0.097 & 0.625 \\
\hline & $(0.107)$ & $(0.343)$ & $(0.122)$ & $(0.326)$ \\
\hline \multirow[t]{2}{*}{ Vocational college } & -0.165 & 0.291 & -0.067 & 0.726 \\
\hline & $(0.125)$ & $(0.244)$ & $(0.132)$ & $(0.424)$ \\
\hline \multirow[t]{2}{*}{ Academic } & $-0.262^{*}$ & $0.176^{*}$ & -0.017 & 1.024 \\
\hline & $(0.143)$ & $(0.163)$ & $(0.149)$ & $(0.786)$ \\
\hline \multirow[t]{2}{*}{ Work experience } & -0.003 & 0.991 & -0.003 & 0.989 \\
\hline & $(0.005)$ & $(0.021)$ & $(0.004)$ & $(0.015)$ \\
\hline \multirow[t]{2}{*}{ Wage per hour } & $0.009 * *$ & $1.040^{*}$ & 0.004 & 1.022 \\
\hline & $(0.004)$ & $(0.021)$ & $(0.003)$ & $(0.016)$ \\
\hline \multirow[t]{2}{*}{ Permanent contract } & -0.081 & 0.758 & -0.058 & 0.823 \\
\hline & $(0.053)$ & $(0.141)$ & $(0.048)$ & $(0.157)$ \\
\hline \multirow[t]{2}{*}{ Supervisor } & $0.098^{* *}$ & $1.596^{* *}$ & $0.053^{*}$ & 1.235 \\
\hline & $(0.040)$ & $(0.292)$ & $(0.030)$ & $(0.177)$ \\
\hline \multirow[t]{2}{*}{ 2nd job } & -0.116 & $0.551^{*}$ & -0.064 & 0.737 \\
\hline & $(0.079)$ & $(0.191)$ & $(0.055)$ & $(0.180)$ \\
\hline Occupational level & & & & \\
\hline Ref: Medium & & & & \\
\hline Elementary & 0.002 & 0.922 & -0.012 & 1.001 \\
\hline & $(0.087)$ & $(0.404)$ & $(0.061)$ & $(0.369)$ \\
\hline Lower & 0.027 & 1.149 & -0.015 & 0.918 \\
\hline
\end{tabular}


Table 11: TLF arrangements on job satisfaction by children at home (cont.)

\begin{tabular}{|c|c|c|c|c|}
\hline & \multicolumn{2}{|c|}{ No children } & \multicolumn{2}{|c|}{ Child(ren) at home } \\
\hline & Linear FE & BUC (OR) & Linear FE & $\mathrm{BUC}(\mathrm{OR})$ \\
\hline & $(0.038)$ & $(0.241)$ & $(0.030)$ & $(0.134)$ \\
\hline Higher & $\begin{array}{l}0.080^{* *} \\
(0.040)\end{array}$ & $\begin{array}{c}1.334 \\
(0.256)\end{array}$ & $\begin{array}{c}0.040 \\
(0.031)\end{array}$ & $\begin{array}{l}1.200 \\
(0.166)\end{array}$ \\
\hline Scientific & $\begin{array}{r}0.105^{*} \\
(0.063)\end{array}$ & $\begin{array}{c}1.537 \\
(0.466)\end{array}$ & $\begin{array}{c}0.019 \\
(0.047)\end{array}$ & $\begin{array}{c}1.025 \\
(0.225)\end{array}$ \\
\hline Empl. status change & $\begin{array}{l}0.121^{* * *} \\
(0.032)\end{array}$ & $\begin{array}{l}1.619^{* * *} \\
(0.234)\end{array}$ & $\begin{array}{l}0.099^{* * *} \\
(0.023)\end{array}$ & $\begin{array}{l}1.609^{* * *} \\
(0.167)\end{array}$ \\
\hline No. of employees (/1000) & $\begin{array}{c}0.003 \\
(0.005)\end{array}$ & $\begin{array}{c}1.010 \\
(0.025)\end{array}$ & $\begin{array}{c}-0.006^{*} \\
(0.003)\end{array}$ & $\begin{array}{c}0.979 \\
(0.019)\end{array}$ \\
\hline $\begin{array}{l}\text { Sector } \\
\text { Ref: Agriculture }\end{array}$ & & & & \\
\hline Industry & $\begin{array}{l}-0.003 \\
(0.253)\end{array}$ & $\begin{array}{c}1.252 \\
(0.829)\end{array}$ & $\begin{array}{l}-0.051 \\
(0.146)\end{array}$ & $\begin{array}{c}0.821 \\
(0.468)\end{array}$ \\
\hline Construction & $\begin{array}{l}-0.022 \\
(0.263)\end{array}$ & $\begin{array}{c}1.240 \\
(0.995)\end{array}$ & $\begin{array}{l}-0.140 \\
(0.164)\end{array}$ & $\begin{array}{c}0.598 \\
(0.382)\end{array}$ \\
\hline Trade, gastronomy, repair & $\begin{array}{l}-0.102 \\
(0.267)\end{array}$ & $\begin{array}{c}0.879 \\
(0.590)\end{array}$ & $\begin{array}{c}-0.046 \\
(0.149)\end{array}$ & $\begin{array}{c}0.842 \\
(0.509)\end{array}$ \\
\hline Transport & $\begin{array}{c}0.197 \\
(0.278)\end{array}$ & $\begin{array}{c}2.821 \\
(2.110)\end{array}$ & $\begin{array}{c}0.105 \\
(0.162)\end{array}$ & $\begin{array}{c}1.798 \\
(1.227)\end{array}$ \\
\hline Business services & $\begin{array}{c}0.072 \\
(0.256)\end{array}$ & $\begin{array}{c}1.781 \\
(1.172)\end{array}$ & $\begin{array}{l}-0.024 \\
(0.143)\end{array}$ & $\begin{array}{c}0.943 \\
(0.536)\end{array}$ \\
\hline Care, Welfare & $\begin{array}{c}0.031 \\
(0.270)\end{array}$ & $\begin{array}{c}1.471 \\
(1.045)\end{array}$ & $\begin{array}{c}0.165 \\
(0.157)\end{array}$ & $\begin{array}{c}1.951 \\
(1.226)\end{array}$ \\
\hline Other services & $\begin{array}{c}0.249 \\
(0.268)\end{array}$ & $\begin{array}{r}4.117^{*} \\
(3.083)\end{array}$ & $\begin{array}{c}0.045 \\
(0.161)\end{array}$ & $\begin{array}{c}1.211 \\
(0.777)\end{array}$ \\
\hline Government & $\begin{array}{c}0.106 \\
(0.265)\end{array}$ & $\begin{array}{c}2.109 \\
(1.505)\end{array}$ & $\begin{array}{l}-0.016 \\
(0.159)\end{array}$ & $\begin{array}{c}0.958 \\
(0.630)\end{array}$ \\
\hline Education & $\begin{array}{c}0.346 \\
(0.268)\end{array}$ & $\begin{array}{c}6.245^{* *} \\
(4.736)\end{array}$ & $\begin{array}{c}0.188 \\
(0.181)\end{array}$ & $\begin{array}{c}2.086 \\
(1.472)\end{array}$ \\
\hline Constant & $\begin{array}{l}3.180^{* * *} \\
(0.324)\end{array}$ & - & $\begin{array}{l}3.278^{* * *} \\
(0.218)\end{array}$ & - \\
\hline Observations & 5402 & 2110 & 6890 & 3549 \\
\hline Individuals & 3239 & 672 & 3279 & 973 \\
\hline
\end{tabular}

${ }^{*} p<0.10,{ }^{* *} p<0.05,{ }^{* * *} p<0.01$

Note: Parameter estimates of TLF arrangements on job satisfaction. BUC coefficients are odds-ratios; the reference point is therefore one. Year (wave) dummies included. Clustered standard errors in parentheses. 